\title{
Maternal Supplementation with Cow's Milk Naturally Enriched with PUFA Alters the Metabolism of Sows and the Fatty Acid Profile of the Offspring
}

\author{
Leriana Garcia Reis ${ }^{1}$, Thiago Henrique Silva ${ }^{1}$, Gisele Mouro Ravagnani ${ }^{2}{ }^{\mathbb{D}}$, \\ Cristian Hernando Garcia Martinez ${ }^{3} \mathbb{D}$, Márcia Saladini Vieira Salles ${ }^{4} \mathbb{D}$, André Furugen Cesar Andrade ${ }^{2}{ }^{\mathbb{D}}$, \\ Nara Regina Brandão Cônsolo ${ }^{1,+} \mathbb{D}^{\mathbb{B}}$, Simone Maria Massami Kitamura Martins ${ }^{1}(\mathbb{D}$, \\ Fernando de Oliveira Bussiman ${ }^{3}{ }^{\circ}$, Mauricio Xavier Silva Oliveira ${ }^{5}{ }^{\circ}$, Dante Pazzanese Duarte Lanna ${ }^{6}(\mathbb{C}$ \\ and Arlindo Saran Netto ${ }^{1, *(1)}$
}

check for updates

Citation: Reis, L.G.; Silva, T.H. Ravagnani, G.M.; Martinez, C.H.G.; Salles, M.S.V.; Andrade, A.F.C.; Cônsolo, N.R.B.; Martins, S.M.M.K.; de Oliveira Bussiman, F.; Oliveira, M.X.S.; et al. Maternal

Supplementation with Cow's Milk Naturally Enriched with PUFA Alters the Metabolism of Sows and the Fatty Acid Profile of the Offspring. Nutrients 2021, 13, 1942.

https://doi.org/10.3390/nu13061942

Academic Editor: Frederic Capel

Received: 24 March 2021

Accepted: 3 June 2021

Published: 5 June 2021

Publisher's Note: MDPI stays neutral with regard to jurisdictional claims in published maps and institutional affiliations.

Copyright: (c) 2021 by the authors. Licensee MDPI, Basel, Switzerland. This article is an open access article distributed under the terms and conditions of the Creative Commons Attribution (CC BY) license (https:// creativecommons.org/licenses/by/ $4.0 /)$.
1 Department of Animal Science, School of Animal Science and Food Engineering, University of São Paulo, Avenida Duque de Caxias Norte, 225, Pirassununga 13635-900, Brazil; leriana@usp.br (L.G.R.); silvath@usp.br (T.H.S.); nara.consolo@hotmail.com (N.R.B.C.); smmkm@usp.br (S.M.M.K.M.)

2 Department of Animal Reproduction, School of Veterinary and Animal Science, University of São Paulo, Avenida Duque de Caxias Norte, 225, Pirassununga 13635-900, Brazil; giselemouro@gmail.com (G.M.R.); andrefc@usp.br (A.F.C.A.)

3 Department of Animal Nutrition and Production, School of Veterinary and Animal Science, University of São Paulo, Avenida Duque de Caxias Norte, 225, Pirassununga 13635-900, Brazil;

chmartinez.mvz@usp.br (C.H.G.M.); fernando.bussiman@usp.br (F.d.O.B.)

4 Animal Science Institute, Avenida Bandeirantes, 2419, Ribeirão Preto 14030-640, Brazil; marcia.saladini@gmail.com

5 Department of Animal Science, Ohio Agricultural Research and Development Center, The Ohio State University, Wooster, OH 44691, USA; oliveira.51@osu.edu

6 Department of Animal Science, Luiz de Queiroz College Agriculture, University of São Paulo, Avenida Pádua Dias, 11, Piracicaba 13418-900, Brazil; dplanna@usp.br

* Correspondence: saranetto@usp.br; Tel.: +55-(019)35654000 or +55-(019)35654039 or +55-(019)997270373

+ Current adress: Grasslands Research Centre, AgResearch, Tennent Drive, 11 Dairy Farm Rd, Palmerston North 4442, New Zealand.

Abstract: The study aimed to evaluate the supplementation of gilts with cow's milk naturally enriched with n-3 and n- 6 polyunsaturated fatty acids (PUFA) on reproductive outcomes, and the serum biochemical and FA profile of swine females and their offspring. During 316 days, 30 gilts were distributed into three groups: (1) Control, fed a basal diet + milk from cows without oil; (2) $\mathrm{n}-3$, fed a basal diet + milk from cows fed a diet enriched with linseed oil; (3) n-6, fed a basal diet + milk from cows fed a diet enriched with soybean oil. The gilts receiving the diets containing PUFA had higher serum urea and very-low-density lipoprotein levels and lower serum total protein and low-density lipoprotein levels compared to the Control group. Females supplemented with n-3 presented higher serum palmitic acid and $\gamma$-linolenic acid levels than those fed n-6. Piglets from the Control group were heavier at birth than those from females supplemented with enriched milk. The piglets from females receiving enriched milk had $140 \mathrm{~g}$ higher body weight from 1 to 21 days old compared to the Control group, and greater average daily weight gain from 7 to 14 days old. The serum eicosapentaenoic acid level of piglets fed n-3 was $69 \%$ higher than those fed n-6, which reduced the AA/EPA ratio. Gilts supplemented with PUFA-enriched cow's milk showed changes in their serum palmitic and $\gamma$-linolenic acid levels, in addition to improved performance, EPA concentration and consequently reduced AA/EPA ratio in their piglets, demonstrating beneficial results for their progeny.

Keywords: cholesterol; edible oil; fatty acid metabolism; n-3 fatty acid; n-6 fatty acid; polyunsaturated fatty acid 


\section{Introduction}

Polyunsaturated fatty acids (PUFA) have been emphasised as bioactive compounds correlated with cardiovascular health by reducing the levels of risk factors such as cholesterol level, reduced risk of diabetes and improved human health [1,2]. Maternal supplementation with PUFA may be an essential source of those fatty acids (FA) for foetal and newborn development $[3,4]$, mainly because PUFA can be a precursor of long-chain polyunsaturated fatty acids (LC-PUFA) such as docosahexaenoic acid (DHA) and eicosapentaenoic acid (EPA), which are essential for the development of foetal and infant vision, brain, immune system and inflammatory response and to protect against some allergies and disease [5].

Maternal supplementation can be by the intake of foods with content of those compounds. In this case, milk and dairy products make an important contribution to consumption of essential FA, especially because they are products consumed daily, and also because their composition can be manipulated through the animal's nutrition [6,7]. Studies have shown that PUFA supplementation during gestation and lactation can alter serum the FA profile of neonates, such as of humans [3], dogs [8], sheep [9], goats [10], rats [11] and pigs [12,13]; however, there are no long-term studies using cow milk as a natural source of PUFA.

Animal models are used extensively in nutritional research. The suitability of the pig (Sus scrofa) as a model for human research is becoming accepted, particularly because humans and pigs are classified as omnivorous mammals and share similarities related to anatomical features of the gastrointestinal tract [14]. In this sense, the supplementation of swine with enriched cow milk could be used as a model for human nutrition, providing a deeper understanding about its effect on human nutrition and metabolism. Therefore, we hypothesised that gilts supplemented with cow milk enriched with PUFA would improve their health, as well as the health and performance of their piglets. The objective of this study was to evaluate the effects of supplementation of gilts with cow's milk enriched with n-3 and n- 6 on maternal blood metabolic profile, sow's reproductive outcomes, colostrum and milk composition, colostrum and milk FA profile, piglets' performance and the serum FA profile of both.

\section{Materials and Methods}

The trial was performed in the Swine Research Laboratory of the School of Veterinary Medicine and Animal Science (FMVZ), University of São Paulo. The procedures and experimental use of animals were approved by the Animal Care and Use Committee of the School of Animal Science and Food Engineering at the University of São Paulo (Protocol \#4939070317).

\subsection{Experimental Design}

In this case, 30 hybrid gilts (Landrace $x$ Large White), 34 days old and initial body weight of $9.59 \pm 1.28 \mathrm{~kg}$ until first farrowing, were housed individually and used in a completely randomised design experiment. Gilts were randomly allocated into one of three groups: (1) Control-basal diet + milk from cows without oil supplementation; (2) n-3 - basal diet + milk from cows fed a diet enriched with linseed oil; and (3) n-6 - basal diet + milk from cows fed a diet enriched with soybean oil. The gilts were supplemented with the treatments until their offspring were 21 days old (316 days). The enriched milk was obtained from Holstein cows from the University of São Paulo herd, more details can be find in the study of Oliveira et al. [15]. The cows were supplemented or not with $2.5 \%$ (on a dry matter (DM) basis) of linseed or soybean oil, sources of n-3 and n-6, respectively.

The effects of vegetable oil on the quality of the lipid fraction of the dairy cows' milk provided for gilts are presented in Table 1. From weaning to artificial insemination (AI), the females were supplemented with $200 \mathrm{~mL}$ (days 34-76), $300 \mathrm{~mL}$ (days 77-128), $400 \mathrm{~mL}$ (days 129-174) and $500 \mathrm{~mL}$ (days 175-247) of cows' milk per animal per day (Supplementary Figure S1). From oestrus synchronisation (Regumate ${ }^{\circledR}$, MSD 
Saúde Animal, São Paulo, Brazil) up to the end of the lactation period, females received $1 \mathrm{~L} /$ day of cows' milk. Supplementation with milk was performed daily at 8:00 a.m., after individual feeding.

Table 1. The lipid fraction of milk from Holstein dairy cows fed diets supplemented linseed and soybean oil.

\begin{tabular}{|c|c|c|c|c|c|c|c|}
\hline \multirow{2}{*}{ Fatty Acid Profile ${ }^{a}, g / 100 \mathrm{~g}$} & \multicolumn{3}{|c|}{ Diets $^{b}$} & \multirow{2}{*}{ SEM $^{c}$} & \multicolumn{3}{|c|}{$p$-Value ${ }^{\mathrm{d}}$} \\
\hline & $\mathrm{CON}$ & LIN & SOY & & Treatment & $\mathrm{C1}$ & $\mathrm{C} 2$ \\
\hline$\Sigma$ SFA & 66.89 & 56.60 & 56.52 & 1.441 & $<0.01$ & $<0.01$ & 0.969 \\
\hline$\Sigma$ USFA & 33.05 & 43.35 & 43.39 & 1.438 & $<0.01$ & $<0.01$ & 0.986 \\
\hline SFA/USFA & 2.12 & 1.36 & 1.34 & 0.107 & $<0.01$ & $<0.01$ & $<0.01$ \\
\hline$\Sigma$ MUFA & 29.58 & 39.47 & 39.55 & 1.301 & $<0.01$ & $<0.01$ & 0.966 \\
\hline$\Sigma$ PUFA & 3.57 & 3.98 & 3.93 & 0.275 & 0.199 & 0.076 & 0.860 \\
\hline$\Sigma \mathrm{n}-3$ & 0.32 & 1.02 & 0.36 & 0.029 & $<0.01$ & $<0.01$ & $<0.01$ \\
\hline$\Sigma \mathrm{n}-6$ & 2.48 & 2.25 & 2.88 & 0.208 & 0.004 & 0.589 & 0.001 \\
\hline$n-6 / n-3$ & 7.92 & 2.72 & 8.26 & 0.504 & $<0.01$ & $<0.01$ & $<0.01$ \\
\hline Cholesterol, g/100 mL & 9.94 & 8.74 & 10.05 & 1.649 & 0.174 & 0.403 & 0.097 \\
\hline
\end{tabular}

a $\Sigma$ SFA $=\Sigma$ saturated fatty acids; $\Sigma$ USFA $=\Sigma$ unsaturated fatty acids; SFA/USFA $=\Sigma$ saturated $/ \Sigma$ unsaturated; $\Sigma$ MUFA $=\Sigma$ monounsaturated fatty acids; $\Sigma$ PUFA $=\Sigma$ polyunsaturated fatty acids; $\Sigma \mathrm{n}-3=$ sum of n-3 fatty acids; $\Sigma \mathrm{n}-6=\mathrm{n}-6$ : sum of n- 6 fatty acids; n-6/n-3 = $\Sigma$ omega- $6 / \Sigma$ omega-3. ${ }^{b}$ Cows fed with a Control diet (CON), supplemented with linseed oil (LIN) or soybean oil (SOY). ${ }^{c}$ SEM, standard error of the mean. ${ }^{\mathrm{d}} \mathrm{C} 1$, contrast $\mathrm{CON}$ vs. LIN+SOY; $\mathrm{C} 2$, contrast LIN vs. SOY.

\subsection{Diets}

Water and feed were provided ad libitum and feed was offered according to the phases described below: pre-starter phase, from weaning to 43 days old; starter phase, from 44-72 days old; grower phase, from 73-130 days old; finisher phase, from 131-152 days old; replacement phase, from 155-AI; gestation phase; and lactation. The basal diet was formulated to meet the nutritional requirements of females for each physiological phase according to Rostagno et al. [16]. All diets were based on corn and soybean feedstuffs and did not contain any oil as an ingredient (Table 2). The gilts were fed twice a day, at 7:00 am and 1:00 pm. The descriptive analysis of the FA profile and lipid fraction of diets is shown in Table 3.

\subsection{Management of Swine Females and Data Collection}

After synchronisation, gilts were checked for standing oestrus by placing a entire male pig into the pen for $15 \mathrm{~min} /$ day. Gilts were inseminated with pooled semen every $24 \mathrm{~h}$ until the end of the oestrus. Approximately 21 days after AI, pregnancy was detected using a real-time ultrasound (Scanner $100^{\circledR}, 5 \mathrm{MHz}$ transducer, Pie Medical, Maastricht, The Netherlands). At approximately 107 days of pregnancy, gilts were transferred to individual farrowing crates built of concrete and equipped with slatted floor and an infrared lamp to establish a warm microclimate for the piglets.

All females were closely monitored during farrowing starting from the birth of the first piglet until placenta expulsion. After farrowing, no creep feed was offered. For each litter, the numbers born alive, stillborn or mummified and total piglets born were recorded along with the time of birth and birth weight for each piglet, females were monitored until day 21 of lactation. Colostrum samples $(20 \mathrm{~mL})$ were collected in sterile tubes by manual expression from multiple teats at the moment milk ejection started during farrowing, and milk samples $(50 \mathrm{~mL})$ were collected $14 \mathrm{~d}$ post-farrowing after injection with $1 \mathrm{~mL}$ oxytocin (Ocitovet, Ceva, Brazil) in the ear vein. Colostrum and milk samples were immediately frozen at $-20^{\circ} \mathrm{C}$ until later analysis. The milk composition was analysed using an automatic milk analyser (Lactoscan MCC, Nova Zagora, Bulgaria). 
Table 2. Composition of pre-initial, initial, grower and finisher diets, specific to each physiological phase of swine females.

\begin{tabular}{|c|c|c|c|c|c|c|c|}
\hline Item & Pre-Initial & Initial & Grower & Finisher & Replacement & Gestation & Lactation \\
\hline \multicolumn{8}{|l|}{ Ingredients, $\mathrm{g} / \mathrm{kg}$} \\
\hline Ground corn & 399.0 & 649.0 & 699.0 & 739.0 & 644.4 & 594.0 & 587.8 \\
\hline Soybean meal & 200.0 & 300.0 & 280.0 & 240.0 & 240.8 & 140.0 & 265.1 \\
\hline Wheat bran & - & - & - & - & 86.5 & 240.0 & - \\
\hline UNIMIX $^{a}$ & 400.0 & 50.0 & 20.0 & 20.0 & 25.0 & 25.0 & 30.0 \\
\hline L-lysine & - & - & - & - & - & - & 10.0 \\
\hline DL-methionine & - & - & - & - & - & - & 2.0 \\
\hline Sugar & - & - & - & - & - & - & 100.0 \\
\hline Calcitic limestone & - & - & - & - & 2.3 & - & 4.1 \\
\hline Mycofix & 1.0 & 1.0 & 1.0 & 1.0 & 1.0 & 1.0 & 1.0 \\
\hline \multicolumn{8}{|l|}{ Chemical composition } \\
\hline Dry matter, \% & 83.41 & 87.92 & 87.07 & 88.93 & 88.12 & 89.42 & 88.25 \\
\hline Ashes, \% & 6.69 & 5.43 & 4.80 & 3.70 & 4.54 & 5.23 & 5.62 \\
\hline Crude energy, cal/g & 4347.0 & 4393.0 & 4419.0 & 4465.0 & 4411.5 & 4360.0 & 4376.0 \\
\hline Ether extract, \% & 4.14 & 1.71 & 2.41 & 1.71 & 1.37 & 1.40 & 1.56 \\
\hline Crude fiber, $\%$ & 4.54 & 4.32 & 4.30 & 4.07 & 3.01 & 5.23 & 5.28 \\
\hline Crude protein, $\%$ & 18.04 & 21.21 & 18.07 & 20.46 & 19.04 & 17.59 & 19.99 \\
\hline Calcium, \% & 0.90 & 0.80 & 0.63 & 0.51 & 0.82 & 0.81 & 0.94 \\
\hline Phosphorus, \% & 0.69 & 0.53 & 0.41 & 0.37 & 0.38 & 0.46 & 0.43 \\
\hline
\end{tabular}

a The premix used in each phase was based on Rostagno et al. [16].

Table 3. Fatty acid composition and lipid fraction of diets offered to swine females.

\begin{tabular}{|c|c|c|c|c|c|c|c|}
\hline Fatty Acids ${ }^{a}, g / 100 \mathrm{~g}$ & Pre-Initial & Initial & Grower & Finisher & Replacement & Gestation & Lactation \\
\hline Lauric, C12:0 & 10.63 & 0.17 & 0.01 & 0.07 & 0.01 & 0.03 & 0.01 \\
\hline Myristic, C14:0 & 4.17 & 0.20 & 0.07 & 0.14 & 0.09 & 0.18 & 0.14 \\
\hline Palmitic, C16:0 & 18.24 & 21.31 & 16.19 & 20.52 & 17.92 & 17.72 & 17.47 \\
\hline Stearic, C18:0 & 5.04 & 3.58 & 2.70 & 2.62 & 2.62 & 2.48 & 2.68 \\
\hline Palmitoleic, C16:1c9 & 0.13 & 0.08 & 0.07 & 0.09 & 0.07 & 0.18 & 0.15 \\
\hline Elaidic, C18:1t & 0.21 & n.d. ${ }^{c}$ & n.d. ${ }^{c}$ & n.d. ${ }^{c}$ & n.d. ${ }^{c}$ & 0.06 & 0.05 \\
\hline Oleic, C18:1c9 & 23.75 & 25.72 & 32.63 & 25.46 & 25.52 & 22.11 & 23.39 \\
\hline Vaccenic, C18:1c11 & 1.44 & 1.56 & 1.76 & 1.53 & 1.50 & 1.55 & 1.39 \\
\hline Linoleic, C18:2 n-6 & 28.94 & 43.40 & 43.36 & 46.01 & 48.70 & 51.52 & 50.41 \\
\hline$\alpha$-Linolenic, C18:3 n-3 & 1.84 & 1.78 & 1.59 & 1.71 & 2.11 & 2.26 & 2.35 \\
\hline DHA, C22:06 n-3 & n.d. ${ }^{\mathrm{c}}$ & 0.06 & 0.04 & 0.03 & n.d. ${ }^{\mathrm{c}}$ & 0.07 & 0.06 \\
\hline Others $\mathrm{b}$ & 5.55 & 2.06 & 1.57 & 1.82 & 1.48 & 1.81 & 1.81 \\
\hline$\Sigma$ SFA & 42.96 & 26.73 & 19.86 & 24.43 & 21.45 & 21.33 & 21.32 \\
\hline$\Sigma$ USFA & 56.30 & 72.55 & 79.41 & 74.80 & 77.89 & 77.67 & 77.74 \\
\hline$\Sigma$ MUFA & 26.19 & 27.97 & 35.14 & 27.82 & 27.74 & 24.75 & 25.74 \\
\hline$\Sigma$ PUFA & 30.77 & 45.24 & 44.99 & 47.75 & 50.81 & 53.87 & 52.84 \\
\hline$\Sigma n-3$ & 1.84 & 1.84 & 1.63 & 1.74 & 2.11 & 2.32 & 2.41 \\
\hline$\sum n-6$ & 28.94 & 43.40 & 43.36 & 46.01 & 48.70 & 51.52 & 50.41 \\
\hline SFA/USFA & 0.76 & 0.37 & 0.25 & 0.33 & 0.28 & 0.27 & 0.27 \\
\hline$n-6 / n-3$ & 15.76 & 23.58 & 26.57 & 26.38 & 23.10 & 22.19 & 20.92 \\
\hline Total & 99.92 & 99.93 & 99.99 & 100.00 & 100.00 & 99.95 & 99.90 \\
\hline
\end{tabular}

a DHA: docosahexaenoic acid; $\Sigma$ SFA $=\Sigma$ saturated fatty acids; $\Sigma$ USFA $=\Sigma$ unsaturated fatty acids; $\Sigma$ MUFA $=\Sigma$ monounsaturated fatty acids; $\Sigma$ PUFA $=\Sigma$ polyunsaturated fatty acids; $\Sigma \mathrm{n}-3=\Sigma$ omega-3 fatty acids; $\Sigma \mathrm{n}-6=\Sigma$ omega- 6 fatty acids; SFA $/$ USFA $=\Sigma$ saturated $/ \Sigma$ unsaturated; $\mathrm{n}-6 / \mathrm{n}-3=\Sigma$ omega- $6 / \Sigma$ omega-3. ${ }^{\mathrm{b}}$ Composed of the following fatty acids: C4:0, C6:0, C8:0, C10:0, C10:1, C11:0, C12:1, C13:0 iso, C13:0, C14:0 iso, C14:1c9, C15:0 iso, C15:0 anteiso, C15:0, C17:0 iso, C17:0, C17:1, C18:1 c12, C18:1 c13, C20:0, C20:1, C20:2, C22:0, C22:1n9, C23:0, C24:0, C24:1. ${ }^{\mathrm{c}}$ Not detectable.

The FA profile of diets, colostrum and sow milk was determined by the Animal Nutrition and Growth Laboratory of the Luiz de Queiroz School of Agriculture (ESALQ/USP). Feed samples were collected and approximately $80 \mathrm{mg}$ of each was ground on a 1-mm screen mill and transferred to an extraction tube $(10 \times 1.4 \mathrm{~cm})$, to determine the composition of FA offered. Then, $2 \mathrm{~mL}$ of methanol/acetyl chloride (20:1) was added along with $1 \mathrm{~mL}$ of hexane and the solution placed in a water bath at $90^{\circ} \mathrm{C}$ for $10 \mathrm{~min}$. After cooling to ambient 
temperature, $2 \mathrm{~mL}$ of distilled water was added and centrifuged at $3200 \mathrm{rpm}$ for $5 \mathrm{~min}$. The supernatant liquid was transferred to a chromatography bottle; this method was adapted from Rodríguez-Ruiz et al. [17]. The colostrum and milk samples were defrosted and centrifuged at $4700 \mathrm{rpm}$ for $45 \mathrm{~min}$. Then, $400 \mathrm{mg}$ of fat was removed from the supernatant for fat extraction according to Hara and Radin [18]. Methylation was by a methanolic sodium methoxide solution, according to Christie [19]. The FA profile was determined by gas chromatography (ThermoFinnigan $^{\circledR}$, model Trace 2000, Thermo Fisher Scientific, Waltham, MA, USA), using a fused sílica capillary column, CP-Sil $88(100 \mathrm{~mm} \times 0.25 \mathrm{~mm} \times 0.2 \mathrm{~mm}$; Agilent Technologies, Ankeny, IA, USA). Hydrogen was used as carrier gas at a flow rate of $1.8 \mathrm{~mL} / \mathrm{min}$, and vaporiser and detector temperatures were 250 and $300^{\circ} \mathrm{C}$, respectively. The oven temperature programme was initially $70^{\circ} \mathrm{C}$ with a holding time of $4 \mathrm{~min}$, then $175^{\circ} \mathrm{C}\left(13^{\circ} \mathrm{C} / \mathrm{min}\right)$ with a holding time of $27 \mathrm{~min}, 215^{\circ} \mathrm{C}\left(4^{\circ} \mathrm{C} / \mathrm{min}\right)$ with a holding time of $9 \mathrm{~min}$ and finally an increase by $7{ }^{\circ} \mathrm{C} / \mathrm{min}$ to $230^{\circ} \mathrm{C}$ and standing for $5 \mathrm{~min}$. A $2 \mu \mathrm{L}$ aliquot of the esterified extract was injected into the chromatograph and the identification of FA was performed by comparing the retention times and the percentages of FA using the software Chromquest 4.1 (Thermo Electron, Thermo Fisher Scientific, Waltham, MA, USA). Standards used were Supelco 37 Component FAME Mix (CRM47885, Supelco, St. Louis, MO, USA) and linoleic acid (conjugated methyl ester, O5632, Sigma-Aldrich, St. Louis, MO, USA). The FA concentration was expressed in $\mathrm{g} / 100 \mathrm{~g}$ of fatty acid methyl esters (FAME).

\subsection{Sows' Performance and Profile of Metabolite in Serum}

Sows were weighed on the 1st and 21st day of lactation after the morning feed. The blood samples were collected from a jugular vein on the first day of lactation after morning feeding. Samples were centrifuged at $2000 \times g$ at $\sim 25^{\circ} \mathrm{C}$ for $10 \mathrm{~min}$ and the serum stored at $-20^{\circ} \mathrm{C}$. The following assays were performed to determine the metabolic profile: total cholesterol, high-density lipoprotein (HDL), total protein and serum urea using enzyme kits (VIDA Biotecnologia ${ }^{\circledR}$, Minas Gerais, Brazil). Low-density lipoproteins (LDL) and triacylglycerol were analysed using enzyme kits (LABTEST ${ }^{\circledR}$, Minas Gerais, Brazil) and the serum FA profile was analysed by gas chromatography [20]. The very-low-density lipoprotein (VLDL) concentration was determined indirectly by the following equation [21]: VLDL cholesterol $(\mathrm{mg} / \mathrm{dL})=$ triglyceride concentration $/ 5$. The chemical analyses were determined in the Clinical Analysis Diagnostics laboratory (DAC, Pirassununga, SP, Brazil) using the specific assay kits mentioned above according to the manufacturer's instructions.

\subsection{Management of Piglets and Data Collection}

Routine procedures (teeth clipping, tail docking, ear notching and iron injection) were conducted 2 days after farrowing, and no creep feed was offered. The piglets were weighed at birth before the first suckling and at 7,14 and 21 days old and average daily gain (ADG) was measured. The basal diet was provided from d 14 of old up to $\mathrm{d} 21$ when the piglets were weaned. Both water and feed were offered ad libitum. Blood samples were collected at birth (before the first suckling) and at 14 days old by jugular vein puncture into an amber tube without EDTA for analysis of the serum FA profile by gas chromatography [20].

\subsection{Chemical Analysis of Diets}

The nutritional levels of diets were analysed in duplicate according to the rules of the Official Association of Analytical Chemists [22]. Analyses of DM (method 930.15), ashes (method 942.05), crude energy (EB), total phosphorus ( $\mathrm{P}$, method 946.05), calcium (Ca, method 978.02) and nitrogen (N) was made using the Kjeldahl digestion and distillation procedure (TE-036/1, Tecnal, Brazil) and the crude protein was calculated as $\mathrm{N} \times 6.25$ (method 990.03), and crude fibre (CF) [23]. The ether extract (EE) was analysed in duplicate according to the rules of the Official Association of Analytical Chemists [24].

Lipids were extracted from samples of the diets according to the Folch method using chloroform/methanol at 2:1 v/v [25]. A sample of approximately $1 \mathrm{~g}$ was used to determine the FA composition of the diets offered. A frozen sample was homogenised in $20 \mathrm{~mL}$ of 
a solution of chloroform/methanol (2:1) using a Turrax homogeniser, disintegrator and emulsifier. After that, an aliquot of lipid extract was methylated according to [26]. The quantification of lipids used was by GC 2010 gas chromatograph (Shimadzu Corp., Kyoto, Japan) with a SP-2560 capillary column $(100 \mathrm{~mL} \times 0.20 \mathrm{~mm}$ D with $0.02 \mu \mathrm{m}$ film thickness; Supelco, Bellefonte, PA, USA). Initially the temperature was adjusted to $70^{\circ} \mathrm{C}$ for 4 min and then increased by $13^{\circ} \mathrm{C} / \mathrm{min}$ until reaching $175^{\circ} \mathrm{C}$ and then maintained for $27 \mathrm{~min}$. The temperature was then increased by $4{ }^{\circ} \mathrm{C} / \mathrm{min}$ to $215^{\circ} \mathrm{C}$ and then maintained for $31 \mathrm{~min}$. Hydrogen was used as carrier gas at a flow rate of $40 \mathrm{~cm}^{3} / \mathrm{s}$.

\subsection{Statistical Analyses}

All statistical analyses were performed using SAS version 9.4 (SAS Inst. Inc., Cary, NC, USA). The data were analysed in a completely randomised design, and the animal was considered as an experimental unit. The animals were distributed randomly into one of three treatments. The normality of the residuals was verified by the Shapiro-Wilk test (PROC UNIVARIATE from SAS) and information with studentized residuals greater than +3 or less than -3 were excluded from the analyses. The Levene test compared the homogeneity of the variances. Variables with continuous distribution were analysed using the SAS MIXED procedure (SAS Institute Inc.). When the residuals did not follow a gaussian distribution, log transformation was applied and if the residuals remained not being normal distributed a generalized linear model was used with Log-Normal distribution. When the time factor was not present, the statistical model included 'treatment' as a fixed effect, 'animal' and 'residual' as random effects. When the time factor was present, repeated measures in time were performed, in which the statistical model included the fixed effects of 'treatment', 'time' and 'treatment by time interaction'. The 'animal effect' and 'residual' were considered to be random. The discrete variables, such as total number of piglets born per litter, number of piglets born alive per litter, number of stillbirths per litter, number of mummifieds per litter and time to reach the ceiling were analyzed using the GLIMMIX procedure, Poisson distribution. The Kenward-Roger method was used to approximate the degree of freedom of the denominator for the F-test in statistical models. The covariance structure for each parameter was determined based on the lowest value of the Akaike information criteria. In addition, data from the first measurement of weight and weight on the day of delivery were used as covariates in statistical statistics when appropriate. The treatments were analyzed as orthogonal contrast, with contrast $1(\mathrm{C} 1)$ : Control group vs. $n-3+n-6$, and contrast 2 (C2): $n-3$ vs. $n-6$. The differences were considered significant at $p<0.05$, and a trend was considered when $0.05<p \leq 0.10$.

\section{Results}

\subsection{Sows' Performance, Serum Metabolite Profile and Colostrum FA Profile}

No differences were found in the average body weight of the females during lactation (Control 179.29 kg; n-3 183.29 kg; n-6 180.62 kg; Supplementary Table S1). The highest percentage of body weight loss was observed for the Control group $(9.42 \%), n-3(6.48 \%)$ and n-6 (7.92\%) during lactation ( $\mathrm{d} 1-21 ; p>0.05)$. This weight difference was greater by $70.22 \%$ and $49 \%$ for the Control group and $n-6$ compared to $n-3(p>0.05)$, respectively. The n-3 group presented a gain of $5.27 \%$ in backfat thickness, while in the other groups losses were observed (2.76\% in Control group and $4.18 \%$ in $n-6)$ from $d 1-21(p>0.05)$. Based on n-3 females, the Control and n-6 groups showed losses of $158.62 \%$ and $185.06 \%$, respectively $(p>0.05)$, in backfat thickness (Supplementary Table S1).

On the first day of lactation, females supplemented with milk enriched with n-3 and n-6 presented higher serum concentration of urea $(p<0.001)$ and VLDL $(p=0.043)$, and lower total protein $(p=0.010)$ and LDL $(p=0.012)$ concentrations (Table 4$)$. There was a trend to increase serum triglyceride concentration $(p=0.062)$ in sows fed $n-3$ and $n-6$ compared to the Control (Table 4$)$. However, no differences $(p<0.100)$ were found for total serum cholesterol, glucose or HDL concentrations among treatments, and there was no difference in serum biochemical parameters between treatments n-3 and n-6 (Table 4). 
Table 4. Concentrations of urea, total protein, total cholesterol, glucose, triglycerides, HDL, LDL and VLDL in the serum of sows on the first day of lactation.

\begin{tabular}{|c|c|c|c|c|c|c|c|}
\hline \multirow{2}{*}{ Biochemical Parameters } & \multicolumn{3}{|c|}{ Treatments $^{a}$} & \multirow{2}{*}{ SEM $^{b}$} & \multicolumn{3}{|c|}{$p$-Value ${ }^{c}$} \\
\hline & Control & n-3 & $n-6$ & & Treatment & $\mathrm{C} 1$ & $\mathrm{C} 2$ \\
\hline Urea, mg/dL & 23.70 & 28.22 & 24.88 & 1.689 & 0.841 & $<0.001$ & 0.841 \\
\hline Total protein, $\mathrm{g} / \mathrm{dL}$ & 6.93 & 6.24 & 6.50 & 0.165 & 0.022 & 0.010 & 0.285 \\
\hline Total cholesterol, mg/dL & 53.90 & 46.44 & 47.80 & 3.450 & 0.281 & 0.120 & 0.775 \\
\hline Glucose, $\mathrm{mg} / \mathrm{dL}$ & 70.60 & 77.22 & 74.55 & 3.610 & 0.478 & 0.266 & 0.636 \\
\hline Triglycerides, mg/dL & 24.09 & 31.11 & 35.33 & 3.950 & 0.117 & 0.062 & 0.327 \\
\hline $\mathrm{HDL}, \mathrm{mg} / \mathrm{dL}$ & 16.50 & 14.77 & 14.88 & 1.480 & 0.654 & 0.362 & 0.959 \\
\hline $\mathrm{LDL}, \mathrm{mg} / \mathrm{dL}$ & 32.66 & 26.13 & 24.76 & 2.280 & 0.039 & 0.012 & 0.684 \\
\hline VLDL, mg/dL & 4.70 & 6.22 & 7.11 & 0.758 & 0.094 & 0.043 & 0.427 \\
\hline
\end{tabular}

${ }^{\text {a }}$ Sows fed with a Control milk (Control), supplemented with cow's milk enriched with n-3 or n-6. ${ }^{b}$ SEM, standard error of the mean. ${ }^{c} \mathrm{C} 1$, contrast Control vs. n-3+n-6; C2, contrast n-3 vs. n-6.

According to the sows' serum FA profile on the first day of lactation (Table 5), females supplemented with n-3-enriched milk had $17.58 \%$ higher palmitic acid $(16: 0 ; p=0.012)$ and $47.92 \%$ higher $\gamma$-linolenic acid (18:3n6; $p=0.031)$ compared to $\mathrm{n}-6$ sows. For stearic acid, sows fed n-3 had a tendency towards lower concentration than those fed $\mathrm{n}-6$ (18:0; $p=0.066$, Table 5). Furthermore, females that received enriched milk tended to show decreased serum linoleic acid (18:2n-6; $p=0.079)$, PUFA $(p=0.084)$ and total $n-6(p=0.081)$ when compared to the Control group (Table 5). Colostrum from females supplemented with enriched milk tended to have lower protein $(p=0.075)$ and lactose values $(p=0.087)$ compared to the Control group (Table 6) on day 14 of lactation. The other variables of serum FA profile and colostrum composition were not different among treatments $(p>0.05)$.

Table 5. Fatty acid profile of the serum of sows on the first day of lactation.

\begin{tabular}{|c|c|c|c|c|c|c|c|}
\hline \multirow{2}{*}{ Fatty Acids ${ }^{a}, \mu g / m L$} & \multicolumn{3}{|c|}{ Treatments $b$} & \multirow{2}{*}{ SEM $^{c}$} & \multicolumn{3}{|c|}{$p$-Value ${ }^{\mathrm{d}}$} \\
\hline & Control & $n-3$ & $n-6$ & & Treatment & C1 & $\mathrm{C} 2$ \\
\hline Myristic, C14:0 & 0.47 & 0.63 & 0.54 & 0.378 & 0.652 & 0.562 & 0.568 \\
\hline Palmitic, C16:0 & 16.80 & 18.53 & 15.76 & 0.613 & 0.029 & 0.709 & 0.012 \\
\hline Stearic, C18:0 & 13.08 & 13.48 & 16.45 & 1.029 & 0.133 & 0.252 & 0.066 \\
\hline Elaidic, C18:1t & 0.20 & 0.28 & 0.22 & 0.036 & 0.323 & 0.398 & 0.281 \\
\hline Palmitoleic, C16:1c9 & 0.99 & 1.54 & 1.27 & 0.281 & 0.431 & 0.351 & 0.482 \\
\hline Oleic, C18:1c9 & 22.65 & 22.86 & 25.62 & 1.702 & 0.461 & 0.541 & 0.253 \\
\hline Linoleic, C18:2 n-6 & 32.01 & 29.43 & 25.95 & 1.411 & 0.102 & 0.079 & 0.104 \\
\hline Dihomo- $\gamma$-linolenic, C20:3 n-6 & 0.51 & 0.65 & 0.68 & 0.125 & 0.708 & 0.426 & 0.832 \\
\hline ARA, C20:4 n-6 & 11.77 & 10.78 & 11.91 & 1.035 & 0.647 & 0.786 & 0.425 \\
\hline$\gamma$-Linolenic, C18:3 n-6 & 0.45 & 0.71 & 0.48 & 0.065 & 0.033 & 0.161 & 0.031 \\
\hline$\alpha$-Linolenic, C18:3 n-3 & 0.58 & 0.54 & 0.50 & 0.104 & 0.899 & 0.715 & 0.750 \\
\hline EPA, C20:5 n-3 & 0.29 & 0.34 & 0.30 & 0.042 & 0.675 & 0.659 & 0.517 \\
\hline DHA, C22:6 n-3 & 0.20 & 0.22 & 0.31 & 0.045 & 0.304 & 0.335 & 0.177 \\
\hline$\Sigma S F A$ & 30.35 & 32.65 & 32.74 & 1.030 & 0.348 & 0.348 & 0.287 \\
\hline$\Sigma U S F A$ & 69.65 & 67.35 & 67.26 & 3.090 & 0.432 & 0.167 & 0.948 \\
\hline SFA/USFA & 0.44 & 0.48 & 0.49 & 2.252 & 0.354 & 0.171 & 0.950 \\
\hline$\Sigma$ MUFA & 23.84 & 24.67 & 27.11 & 1.806 & 0.520 & 0.461 & 0.334 \\
\hline$\Sigma$ PUFA & 45.81 & 42.67 & 40.15 & 1.469 & 0.153 & 0.084 & 0.229 \\
\hline$\sum \mathrm{n}-3$ & 1.07 & 1.10 & 1.11 & 0.121 & 0.975 & 0.828 & 0.966 \\
\hline$\sum n-6$ & 44.74 & 41.57 & 39.03 & 1.465 & 0.149 & 0.081 & 0.226 \\
\hline$n-6 / n-3$ & 43.00 & 38.75 & 34.71 & 3.949 & 0.499 & 0.315 & 0.455 \\
\hline ARA/EPA & 41.15 & 32.92 & 39.34 & 5.406 & 0.498 & 0.544 & 0.391 \\
\hline
\end{tabular}

${ }^{a}$ ARA: arachidonic acid; EPA: eicosapentaenoic acid; DHA: docosahexaenoic acid; $\Sigma$ SFA $=\Sigma$ saturated fatty acids; $\Sigma$ USFA = $\Sigma$ unsaturated fatty acids; USFA/SFA: unsaturated/saturated fatty acids; $\Sigma$ MUFA $=\Sigma$ monounsaturated fatty acids; $\Sigma$ PUFA $=\Sigma$ polyunsaturated fatty acids; $\Sigma$ n-3 = sum of n-3 fatty acids; $\Sigma$ n-6 = n-6: sum of n-6 fatty acids; n-6/n-3, ratio of total n-6 to total n-3 fatty acids; ARA/EPA: ratio of arachidonic acid to eicosapentaenoic acid. ${ }^{b}$ Sows fed with a Control milk (Control), supplemented with cow's milk enriched with $n-3$ or n-6. ${ }^{c}$ SEM, standard error of the mean. ${ }^{d}$ C1, contrast Control vs. n-3+n-6; C2, contrast n-3 vs. n-6. 
Table 6. Effects of enriched milk supplementation on colostrum composition of lactating sows.

\begin{tabular}{|c|c|c|c|c|c|c|c|}
\hline \multirow{2}{*}{ Chemical Composition (g/100 g) } & \multicolumn{3}{|c|}{ Treatments $^{a}$} & \multirow{2}{*}{$\operatorname{SEM}^{b}$} & \multicolumn{3}{|c|}{$p$-Value ${ }^{\mathrm{c}}$} \\
\hline & Control & n-3 & $n-6$ & & Treatment & $\mathrm{C} 1$ & $\mathrm{C} 2$ \\
\hline \multicolumn{8}{|l|}{ Colostrum } \\
\hline Fat & - & - & - & - & - & - & - \\
\hline Protein & 6.29 & 5.96 & 5.69 & 0.213 & 0.157 & 0.075 & 0.413 \\
\hline Lactose & 9.46 & 8.97 & 8.61 & 0.320 & 0.184 & 0.087 & 0.454 \\
\hline Solids-not-fat & 17.18 & 16.41 & 15.60 & 0.642 & 0.263 & 0.130 & 0.424 \\
\hline \multicolumn{8}{|l|}{ Milk } \\
\hline Fat & 9.53 & 9.88 & 8.39 & 0.968 & 0.551 & 0.745 & 0.302 \\
\hline Protein & 3.84 & 3.90 & 3.76 & 0.085 & 0.507 & 0.891 & 0.252 \\
\hline Lactose & 5.74 & 5.82 & 5.61 & 0.122 & 0.500 & 0.901 & 0.246 \\
\hline Solids-not-fat & 10.42 & 10.58 & 10.20 & 0.223 & 0.500 & 0.891 & 0.247 \\
\hline
\end{tabular}

a Sows fed with a Control milk (Control), supplemented with cow's milk enriched with n-3 or n-6. ${ }^{\mathrm{b}} \mathrm{SEM}$, standard error of mean. ${ }^{\mathrm{c}} \mathrm{C} 1$, contrast Control vs. $n-3+n-6 ; C 2$, contrast $n-3$ vs. $n-6$.

Sows fed the Control diet had higher concentrations $(p<0.05)$ of isotridecyl $(13: 0$ iso), isomargaric (17:0 iso) and $n-6 / n-3$ ratio and lower concentrations of isopentadecylic (15:0 iso), cis-10-Heptadecenoic (17:1c10), elaidic (18:1t), cis-15-Octadecenoic (18:1c15), $\alpha$-Linolenic (18:3n-3) and $\Sigma$ n- 3 at $\mathrm{d} 1$ of lactation compared to those fed $n-3$ and n- 6 diets (Tables 7 and 8). The treatment was significant $(p<0.05)$ for isopentadecylic $(15: 0$ iso), isomargaric (17:0 iso), elaidic (18:1t), cis-15-Octadecenoic (18:1c15), $\alpha$-Linolenic (18:3 n-3), Nn-3 and n-6/n-3 ratio (Tables 7 and 8 ). Sows supplemented with milk enriched with linseed oil showed an increased $(p<0.05)$ cis-15-Octadecenoic (18:1c15), $\alpha$-Linolenic (18:3 n-3), EPA (20:5 n-3) and $\Sigma$ n-3 and a decreased of pentadecylic (15:0) and n-6/n-3 ratios in their colostrum, compared to the n-6 group (Tables 7 and 8).

Consequently, for the FA profile of sows' milk sampled at 14th day of lactation, the treatment was significant $(p<0.05)$ and the sows in group $\mathrm{n}-3$ had a higher concentration ( $p=0.001)$ of cis-15-Octadecenoic (18:1c15) compared to the $\mathrm{n}-6$ group, but lower concentration of ARA (20:4n-6; $p=0.012)$ compared to the sows fed n-3 (Table 9). Additionally, sows fed the $n-3$ diet presented a lower $(p=0.026) n-6 / n-3$ ratio in milk at $d 14$ of lactation compared to those fed the n-6 diet (Table 10).

\subsection{Piglets Performance and Profile of Metabolite in Serum}

Piglets fed the Control diet had shorter time to first suckle $(p<0.001)$ than the other groups, and the n-3 group also presented lower time $(p<0.001)$ compared to the $n-6$ animals. There were no differences in the numbers of total piglets born, born alive, stillborn or mummified per litter $(p>0.05$, Table 11). Piglets born to females supplemented with enriched milk had a lower birth weight $(p<0.001)$, an increase of $140 \mathrm{~g}$ in the total weight from d $1-21(p=0.004)$ and greater weight gains from $\mathrm{d} 7-14$ by $18.75 \%(p=0.003$, Table 11$)$ compared to the Control group.

Piglets born from sows supplemented with n-6 milk had higher weight at birth $(p<0.001)$ and at $\mathrm{d} 21$ after birth $(p=0.035)$ than piglets born from the $\mathrm{n}-3$ group (Table 11). The average weight gain from $\mathrm{d} 1-7$, and from $\mathrm{d} 14-21$, were not different among treatments $(p>0.05)$. As expected, there was an increase in body weight and weight gain for piglets over time $(p<0.001)$ where body weight increased from $1.2167 \mathrm{~kg}$ to $4.5533 \mathrm{~kg}$, and weight gain from $0.1400 \mathrm{~kg}$ to $0.1567 \mathrm{~kg}$, regardless treatment. Piglets from n-3 and n-6 treatments had greater body weight gain from 1 to 21 days of age compared to the Control group. As a consequence, from the age of 1 to 21 days, there was an effect for time $(p<0.001$; Table 11). 
Table 7. Effect of supplementation of milk enriched with n-3 and n-6 on the fatty acid profile of sows' colostrum.

\begin{tabular}{|c|c|c|c|c|c|c|c|}
\hline \multirow{2}{*}{ Fatty Acid Profile ${ }^{a}, g / 100 \mathrm{~g}$} & \multicolumn{3}{|c|}{ Treatments $^{b}$} & \multirow{2}{*}{$\operatorname{SEM}^{\mathrm{c}}$} & \multicolumn{3}{|c|}{$p$-Value ${ }^{\mathrm{d}}$} \\
\hline & Control & $n-3$ & $n-6$ & & Treatment & $\mathrm{C} 1$ & $\mathrm{C} 2$ \\
\hline Caproic, C6:0 & 0.011 & $0.000 *$ & $0.000 *$ & 0.003 & 0.309 & 0.133 & 1.000 \\
\hline Caprylic, C8:0 & 0.000 * & $0.000 *$ & $0.000 *$ & 0.000 & 0.619 & 0.337 & 1.000 \\
\hline Capric, C11:0 & 0.010 & 0.009 & 0.008 & 0.001 & 0.834 & 0.623 & 0.743 \\
\hline Hendecanoic, C11:0 & 0.001 & 0.001 & $0.000 *$ & 0.000 & 0.844 & 0.617 & 0.781 \\
\hline Lauric, C12:0 & 0.062 & 0.053 & 0.047 & 0.005 & 0.453 & 0.265 & 0.579 \\
\hline Isotridecyl, $\mathrm{C} 13: 0$ iso & 0.005 & $0.000 *$ & $0.000^{*}$ & 0.002 & 0.400 & 0.341 & 0.342 \\
\hline Anteisotridecylic, C13:0 anteiso & 0.018 & $0.000 *$ & $0.000^{*}$ & 0.003 & 0.092 & 0.032 & 1.000 \\
\hline Tridecylic, C13:0 & 0.004 & 0.003 & 0.001 & 0.001 & 0.085 & 0.131 & 0.086 \\
\hline Isomyristic, $\mathrm{C} 14: 0$ iso & 0.012 & 0.009 & 0.008 & 0.001 & 0.124 & 0.047 & 0.802 \\
\hline Myristic, C14:0 & 2.424 & 2.516 & 2.216 & 0.110 & 0.556 & 0.813 & 0.300 \\
\hline Isopentadecylic, $\mathrm{C} 15: 0$ iso & 0.047 & 0.051 & 0.082 & 0.005 & 0.004 & 0.024 & 0.005 \\
\hline Anteisopentadecylic, C15:0 anteiso & 0.076 & 0.072 & 0.066 & 0.003 & 0.498 & 0.336 & 0.504 \\
\hline Pentadecylic, C15:0 & 0.249 & 0.268 & 0.235 & 0.008 & 0.271 & 0.870 & 0.115 \\
\hline Isopalmitic, $\mathrm{C} 16: 0$ iso & 0.033 & 0.025 & 0.031 & 0.002 & 0.351 & 0.334 & 0.281 \\
\hline Palmitic, C16:0 & 25.550 & 24.526 & 25.360 & 0.295 & 0.346 & 0.346 & 0.266 \\
\hline Isomargaric, $\mathrm{C} 17: 0$ iso & 0.033 & 0.022 & 0.015 & 0.002 & 0.001 & 0.001 & 0.084 \\
\hline Margaric, C17:0 & 0.385 & 0.421 & 0.404 & 0.013 & 0.573 & 0.365 & 0.607 \\
\hline Stearic, C18:0 & 5.347 & 5.160 & 5.529 & 0.151 & 0.641 & 0.995 & 0.356 \\
\hline Arachidic, C20:0 & 0.094 & 0.082 & 0.091 & 0.003 & 0.344 & 0.300 & 0.303 \\
\hline Behenic, C22:0 & 0.057 & 0.054 & 0.054 & 0.003 & 0.906 & 0.664 & 0.981 \\
\hline Tricosylic, C23:0 & 0.015 & 0.016 & 0.011 & 0.001 & 0.234 & 0.615 & 0.108 \\
\hline Lignoceric, C24:0 & 0.069 & 0.061 & 0.078 & 0.006 & 0.536 & 0.994 & 0.274 \\
\hline Lauroleic, C12:1 & $0.000^{*}$ & 0.001 & 0.001 & 0.000 & 0.397 & 0.187 & 0.834 \\
\hline Myristoleic, C14:1c9 & 0.050 & 0.050 & 0.038 & 0.004 & 0.357 & 0.468 & 0.219 \\
\hline Palmitoleic, C16:1c9 & 2.656 & 2.377 & 2.502 & 0.100 & 0.420 & 0.275 & 0.631 \\
\hline cis-10-Heptadecenoic, C17:1c10 & 0.263 & 0.305 & 0.314 & 0.010 & 0.091 & 0.034 & 0.683 \\
\hline Elaidic, C18:1t & 0.494 & 0.704 & 0.713 & 0.038 & 0.016 & 0.005 & 0.900 \\
\hline Oleic, C18:1c9 & 32.282 & 31.780 & 32.843 & 0.547 & 0.759 & 0.981 & 0.467 \\
\hline Vaccenic, C18:1c11 & 3.859 & 3.722 & 3.882 & 0.091 & 0.770 & 0.785 & 0.513 \\
\hline cis-12-Octadecenoic, C18:1c12 & 0.380 & 0.379 & 0.356 & 0.010 & 0.562 & 0.570 & 0.370 \\
\hline cis-13-Octadecenoic, C18:1c13 & 0.210 & 0.175 & 0.201 & 0.007 & 0.130 & 0.145 & 0.146 \\
\hline trans-16-Octadecenoic, C18:1t16 & 0.035 & 0.037 & 0.040 & 0.003 & 0.696 & 0.521 & 0.587 \\
\hline cis-15-Octadecenoic, C18:1c15 & 0.008 & 0.068 & 0.010 & 0.008 & $<0.001$ & $<0.001$ & $<0.001$ \\
\hline Gondoic, C20:1 & 0.293 & 0.273 & 0.271 & 0.008 & 0.486 & 0.241 & 0.921 \\
\hline Erucic, C22:1 & 0.098 & 0.127 & 0.121 & 0.006 & 0.127 & 0.050 & 0.663 \\
\hline Nervonic, C24:1 & 0.119 & 0.139 & 0.151 & 0.009 & 0.364 & 0.196 & 0.576 \\
\hline Linoleic, C18:2 n-6 & 21.612 & 23.177 & 21.260 & 0.535 & 0.319 & 0.596 & 0.162 \\
\hline$\gamma$-Linolenic, $18: 3$ n-6 & 0.206 & 0.198 & 0.208 & 0.011 & 0.938 & 0.918 & 0.737 \\
\hline$\alpha$-Linolenic, $18: 3$ n-3 & 0.783 & 1.081 & 0.827 & 0.042 & 0.001 & 0.007 & 0.001 \\
\hline Octadeca-9,11-dienoic, C18:2c9t11 & 0.073 & 0.092 & 0.073 & 0.006 & 0.321 & 0.418 & 0.205 \\
\hline 11cis-14cis-Eicosadienoic, C20:2 & 0.327 & 0.282 & 0.288 & 0.014 & 0.400 & 0.188 & 0.863 \\
\hline Dihomo- $\gamma$-linolenic, 20:3 n-6 & 0.252 & 0.217 & 0.238 & 0.011 & 0.431 & 0.299 & 0.442 \\
\hline Dihomo- $\alpha$-linolenic, 20:3 n-3 & 0.043 & 0.038 & 0.035 & 0.003 & 0.564 & 0.330 & 0.686 \\
\hline ARA, C20:4 n-6 & 1.048 & 0.998 & 0.976 & 0.038 & 0.762 & 0.489 & 0.833 \\
\hline Docosa-13,16-dienoic, C22:2c13c16 & 0.031 & 0.030 & 0.029 & 0.002 & 0.973 & 0.757 & 0.901 \\
\hline EPA, C20:5 n-3 & 0.028 & 0.032 & 0.019 & 0.002 & 0.052 & 0.531 & 0.020 \\
\hline Clupadonic, C22:5 & 0.296 & 0.308 & 0.308 & 0.018 & 0.960 & 0.780 & 1.000 \\
\hline DHA, C22:6 n-3 & 0.074 & 0.056 & 0.063 & 0.008 & 0.605 & 0.348 & 0.896 \\
\hline
\end{tabular}

a ARA: arachidonic acid; EPA: eicosapentaenoic acid; DHA: docosahexaenoic acid. ${ }^{b}$ Sows fed with a Control milk (Control), supplemented with cow's milk enriched with n-3 or n-6; $0.000^{*}$ : Values lower than $10^{-6} \mathrm{~g} / 100 \mathrm{~g}$. ${ }^{\mathrm{c}} \mathrm{SEM}$, standard error of the mean. ${ }^{\mathrm{d}} \mathrm{C} 1$, contrast Control vs. $n-3+n-6 ; C 2$, contrast $n-3$ vs. $n-6$. 
Table 8. Effect of supplementation of milk enriched with n-3 and n-6 on the quality of the lipid fraction of sows' colostrum.

\begin{tabular}{cccccccc}
\hline \multirow{2}{*}{ Item $^{\mathbf{a}}$} & \multicolumn{3}{c}{ Treatments $^{\mathbf{b}}$} & \multicolumn{3}{c}{$p$-Value } \\
\cline { 2 - 8 } & Control & $\mathbf{n - 3}$ & $\mathbf{n - 6}$ & SEM $^{\mathbf{c}}$ & Treatment & $\mathbf{C 1}$ & $\mathbf{C 2}$ \\
\hline$\Sigma$ SFA & 34.50 & 33.35 & 34.24 & 0.341 & 0.380 & 0.345 & 0.308 \\
$\Sigma$ USFA & 65.52 & 66.64 & 65.77 & 0.338 & 0.390 & 0.357 & 0.310 \\
$\Sigma$ MUFA & 40.75 & 40.14 & 41.44 & 0.648 & 0.742 & 0.977 & 0.449 \\
$\Sigma$ PUFA & 24.77 & 26.51 & 24.32 & 0.611 & 0.328 & 0.624 & 0.164 \\
$\Sigma$ n-3 & 0.93 & 1.21 & 0.94 & 0.045 & 0.005 & 0.045 & 0.005 \\
$\Sigma$ n-6 & 23.12 & 24.59 & 22.68 & 0.556 & 0.367 & 0.667 & 0.184 \\
SFA /USFA & 0.53 & 0.50 & 0.52 & 0.008 & 0.294 & 0.344 & 0.194 \\
n-6/n-3 & 25.18 & 20.40 & 24.10 & 0.714 & 0.001 & 0.016 & 0.003 \\
\hline
\end{tabular}

a $\Sigma$ SFA $=\Sigma$ saturated fatty acids; $\Sigma$ USFA $=\Sigma$ unsaturated fatty acids; $\Sigma$ MUFA $=\Sigma$ monounsaturated fatty acids; $\Sigma$ PUFA $=\Sigma$ polyunsaturated fatty acids; $\Sigma \mathrm{n}-3=$ sum of n-3 fatty acids; $\Sigma \mathrm{n}-6=\mathrm{n}-6$ : sum of n- 6 fatty acids; SFA $/$ USFA $=\Sigma$ saturated $/ \Sigma$ unsaturated; $\mathrm{n}-6 / \mathrm{n}-3=\Sigma$ omega- $-6 / \Sigma$ omega-3. ${ }^{\mathrm{b}}$ Sows fed with a Control milk (Control), supplemented with cow's milk enriched with n-3 or n-6. ${ }^{\mathrm{c}} \mathrm{SEM}$, standard error of the mean. ${ }^{\mathrm{d}} \mathrm{C} 1$, contrast Control vs. n-3+n-6; 2 , contrast n-3 vs. $n-6$.

Table 9. Effect of supplementation of milk enriched with n-3 and n-6 on the fatty acid profile of sows' milk sampled at d 14 of lactation.

\begin{tabular}{|c|c|c|c|c|c|c|c|}
\hline \multirow{2}{*}{ Fatty Acid Profile ${ }^{a}, g / 100 \mathrm{~g}$} & \multicolumn{3}{|c|}{ Treatments $^{b}$} & \multirow[b]{2}{*}{ SEM $^{c}$} & \multicolumn{3}{|c|}{$p$-Value ${ }^{\mathrm{d}}$} \\
\hline & Control & $n-3$ & $n-6$ & & Treatment & $\mathrm{C} 1$ & $\mathrm{C} 2$ \\
\hline Butiric, C4:0 & 0.025 & 0.027 & 0.032 & 0.003 & 0.627 & 0.448 & 0.561 \\
\hline Caproic, C6:0 & 0.019 & 0.022 & 0.037 & 0.004 & 0.119 & 0.196 & 0.098 \\
\hline Caprylic, C8:0 & 0.031 & 0.040 & 0.041 & 0.004 & 0.561 & 0.293 & 0.956 \\
\hline Capric, C11:0 & 0.189 & 0.250 & 0.238 & 0.027 & 0.659 & 0.379 & 0.862 \\
\hline Caproleic, C10:1c9 & 0.016 & 0.031 & 0.028 & 0.004 & 0.312 & 0.135 & 0.775 \\
\hline Hendecanoic, C11:0 & 0.002 & 0.001 & 0.001 & 0.000 & 0.384 & 0.180 & 0.817 \\
\hline Lauric, C12:0 & 0.307 & 0.334 & 0.320 & 0.023 & 0.906 & 0.710 & 0.818 \\
\hline Isotridecyl, $\mathrm{C} 13: 0$ iso & 0.003 & 0.001 & 0.002 & 0.001 & 0.655 & 0.493 & 0.552 \\
\hline Anteisotridecylic, C13:0 anteiso & 0.002 & 0.000 * & $0.000 *$ & 0.001 & 0.397 & 0.183 & 1.000 \\
\hline Lauroleic, C12:1 & 0.004 & 0.006 & 0.005 & 0.001 & 0.762 & 0.513 & 0.605 \\
\hline Tridecylic, C13:0 & 0.004 & 0.004 & 0.003 & 0.001 & 0.833 & 0.680 & 0.668 \\
\hline Isomyristic, $\mathrm{C} 14: 0$ isso & 0.004 & 0.005 & 0.003 & 0.001 & 0.235 & 0.262 & 0.230 \\
\hline Myristic, C14:0 & 3.218 & 3.650 & 3.570 & 0.196 & 0.666 & 0.384 & 0.876 \\
\hline Isopentadecylic, C15:0 iso & 0.076 & 0.031 & 0.048 & 0.011 & 0.253 & 0.129 & 0.523 \\
\hline Anteisopentadecylic, C15:0 anteiso & 0.041 & 0.038 & 0.041 & 0.002 & 0.874 & 0.777 & 0.672 \\
\hline Myristoleic, C14:1c9 & 0.203 & 0.304 & 0.262 & 0.034 & 0.494 & 0.249 & 0.595 \\
\hline Pentadecylic, C15:0 & 0.134 & 0.122 & 0.120 & 0.007 & 0.722 & 0.431 & 0.939 \\
\hline Isopalmitic, $\mathrm{C} 16: 0$ iso & 0.015 & 0.017 & 0.017 & 0.002 & 0.798 & 0.751 & 0.563 \\
\hline Palmitic, C16:0 & 27.363 & 28.150 & 28.129 & 0.877 & 0.927 & 0.704 & 0.993 \\
\hline Isomargaric, $\mathrm{C} 17: 0$ iso & 0.112 & 0.017 & 0.020 & 0.032 & 0.540 & 0.739 & 0.281 \\
\hline Palmitoleic, C16:1c9 & 7.722 & 9.438 & 9.709 & 0.881 & 0.642 & 0.360 & 0.906 \\
\hline Margaric, C17:0 & 0.279 & 0.223 & 0.229 & 0.016 & 0.292 & 0.126 & 0.879 \\
\hline cis-10-Heptadecenoic, C17:1c10 & 0.380 & 0.404 & 0.350 & 0.015 & 0.355 & 0.913 & 0.159 \\
\hline Stearic, C18:0 & 4.761 & 3.727 & 3.935 & 0.319 & 0.405 & 0.195 & 0.795 \\
\hline Elaidic, C18:1t & 0.382 & 0.365 & 0.450 & 0.023 & 0.292 & 0.603 & 0.144 \\
\hline Oleic, C18:1c9 & 36.788 & 36.110 & 35.053 & 1.300 & 0.878 & 0.689 & 0.761 \\
\hline Vaccenic, C18:1c11 & 3.637 & 3.633 & 3.724 & 0.135 & 0.959 & 0.896 & 0.803 \\
\hline cis-12-Octadecenoic, C18:1c12 & 0.362 & 0.386 & 0.375 & 0.032 & 0.959 & 0.802 & 0.897 \\
\hline cis-13-Octadecenoic, C18:1c13 & 0.199 & 0.173 & 0.196 & 0.011 & 0.480 & 0.569 & 0.325 \\
\hline trans-16-Octadecenoic, C18:1t16 & 0.032 & 0.029 & 0.025 & 0.002 & 0.510 & 0.352 & 0.498 \\
\hline cis-15-Octadecenoic, C18:1c15 & 0.009 & 0.021 & 0.006 & 0.002 & 0.004 & 0.075 & 0.001 \\
\hline Linoleic, C18:2 n-6 & 11.602 & 10.571 & 11.062 & 0.249 & 0.254 & 0.148 & 0.420 \\
\hline Arachidic, C20:0 & 0.067 & 0.056 & 0.064 & 0.003 & 0.275 & 0.195 & 0.230 \\
\hline$\gamma$-Linolenic, $18: 3$ n-6 & 0.102 & 0.071 & 0.094 & 0.010 & 0.260 & 0.138 & 0.265 \\
\hline
\end{tabular}


Table 9. Cont.

\begin{tabular}{|c|c|c|c|c|c|c|c|}
\hline \multirow{2}{*}{ Fatty Acid Profile ${ }^{a}, \mathrm{~g} / 100 \mathrm{~g}$} & \multicolumn{3}{|c|}{ Treatments $b$} & \multicolumn{4}{|c|}{$p$-Value ${ }^{\mathrm{d}}$} \\
\hline & Control & $n-3$ & $n-6$ & SEM $^{c}$ & Treatment & $\mathrm{C1}$ & $\mathrm{C} 2$ \\
\hline$\alpha$-Linolenic, $18: 3$ n-3 & 0.470 & 0.485 & 0.475 & 0.010 & 0.849 & 0.667 & 0.714 \\
\hline Gondoic, C20:1 & 0.312 & 0.284 & 0.266 & 0.026 & 0.804 & 0.549 & 0.806 \\
\hline Octadeca-9,11-dienoic, C18:2c9t11 & 0.058 & 0.057 & 0.063 & 0.006 & 0.914 & 0.870 & 0.702 \\
\hline 11cis-14cis-Eicosadienoic, C20:2 & 0.178 & 0.156 & 0.155 & 0.018 & 0.855 & 0.584 & 0.983 \\
\hline Dihomo- $\gamma$-linolenic, 20:3 n-6 & 0.088 & 0.070 & 0.068 & 0.005 & 0.226 & 0.093 & 0.845 \\
\hline Behenic, C22:0 & 0.022 & 0.025 & 0.025 & 0.002 & 0.769 & 0.478 & 1.000 \\
\hline Dihomo- $\alpha$-linolenic, 20:3 n-3 & 0.021 & 0.019 & 0.015 & 0.003 & 0.574 & 0.521 & 0.558 \\
\hline ARA, C20:4 n-6 & 0.420 & 0.366 & 0.459 & 0.019 & 0.036 & 0.900 & 0.012 \\
\hline Erucic, C22:1 & 0.087 & 0.079 & 0.091 & 0.005 & 0.603 & 0.859 & 0.332 \\
\hline Tricosylic, C23:0 & 0.007 & 0.006 & 0.004 & 0.001 & 0.542 & 0.435 & 0.440 \\
\hline Docosa-13,16-dienoic, C22:2c13c16 & 0.012 & 0.011 & 0.014 & 0.001 & 0.716 & 0.810 & 0.444 \\
\hline EPA, C20:5n-3 & 0.015 & 0.016 & 0.015 & 0.002 & 0.965 & 0.896 & 0.820 \\
\hline Lignoceric, C24:0 & 0.022 & 0.020 & 0.016 & 0.004 & 0.783 & 0.628 & 0.647 \\
\hline Nervonic, C24:1 & 0.079 & 0.054 & 0.063 & 0.009 & 0.552 & 0.318 & 0.694 \\
\hline Clupadonic, C22:5 & 0.107 & 0.091 & 0.089 & 0.005 & 0.268 & 0.117 & 0.759 \\
\hline DHA, C22:6 n-3 & 0.017 & 0.007 & 0.037 & 0.007 & 0.073 & 0.498 & 0.133 \\
\hline
\end{tabular}

a ARA: arachidonic acid; EPA: eicosapentaenoic acid; DHA: docosahexaenoic acid. ${ }^{\mathrm{b}}$ Sows fed with a Control milk (Control), supplemented with cow's milk enriched with n-3 or n-6; $0.000 *$ : Values lower than $10^{-6} \mathrm{~g} / 100 \mathrm{~g}$. ${ }^{\mathrm{c}} \mathrm{SEM}$, standard error of the mean. ${ }^{\mathrm{d}} \mathrm{C} 1$, contrast Control vs. n-3+n-6; C2, contrast n-3 vs. n-6.

Table 10. Effect of supplementation of milk enriched with n-3 and n-6 on the quality of the lipid fraction of sows' milk.

\begin{tabular}{|c|c|c|c|c|c|c|c|}
\hline \multirow{2}{*}{ Item $^{a}$} & \multicolumn{3}{|c|}{ Treatments $^{b}$} & \multirow{2}{*}{$\operatorname{SEM}^{c}$} & \multicolumn{3}{|c|}{$p$-Value ${ }^{\mathrm{d}}$} \\
\hline & Control & $n-3$ & $n-6$ & & Treatment & $\mathrm{C} 1$ & $\mathrm{C} 2$ \\
\hline$\Sigma S F A$ & 36.70 & 36.77 & 36.90 & 0.951 & 0.997 & 0.954 & 0.960 \\
\hline$\Sigma$ USFA & 63.30 & 63.23 & 63.15 & 0.950 & 0.998 & 0.961 & 0.973 \\
\hline$\Sigma$ MUFA & 50.21 & 51.32 & 50.60 & 0.869 & 0.887 & 0.711 & 0.759 \\
\hline$\Sigma$ PUFA & 13.09 & 11.92 & 12.55 & 0.287 & 0.267 & 0.172 & 0.376 \\
\hline$\Sigma \mathrm{n}-3$ & 0.52 & 0.53 & 0.54 & 0.011 & 0.779 & 0.665 & 0.586 \\
\hline$\sum n-6$ & 12.21 & 11.08 & 11.68 & 0.264 & 0.226 & 0.146 & 0.347 \\
\hline SFA/USFA & 0.59 & 0.59 & 0.59 & 0.023 & 0.999 & 0.992 & 0.968 \\
\hline$n-6 / n-3$ & 23.41 & 21.04 & 21.57 & 0.452 & 0.069 & 0.026 & 0.594 \\
\hline
\end{tabular}

a $\Sigma$ SFA $=\Sigma$ saturated fatty acids; $\Sigma$ USFA $=\Sigma$ unsaturated fatty acids; $\Sigma$ MUFA $=\Sigma$ monounsaturated fatty acids; $\Sigma$ PUFA $=\Sigma$ polyunsaturated fatty acids; $\Sigma$ n-3 $=$ sum of n-3 fatty acids; $\Sigma$ n- $6=$ n-6: sum of n- 6 fatty acids, SFA $/$ USFA $=\Sigma$ saturated $/ \Sigma$ unsaturated; $\mathrm{n}-6 / \mathrm{n}-3=\Sigma$ omega- $6 / \Sigma$ omega-3. ${ }^{\mathrm{b}}$ Sows fed with a Control milk (Control), supplemented with cow's milk enriched with n-3 or n-6. ${ }^{\mathrm{c}}$ SEM, standard error of the mean. ${ }^{\mathrm{d}} \mathrm{C} 1$, contrast Control vs. n-3+n-6; C2, contrast n-3 vs. n-6.

There were several changes in piglets' FA serum concentration according to the treatments and over time ( $p<0.05$, Table 12), in which most of the FA decreased from 1 to 14 days age, except linoleic, $\alpha$-linolenic, unsaturated, polyunsaturated, total $n-6$ fatty acid and the ratio $n-6 / n-3$, which increased over time. The piglets from sows supplemented with milk enriched with n-3 had a $69 \%$ higher serum EPA (20:5n-3) concentration than those fed $\mathrm{n}-6(p=0.010)$. Consequently, the ARA/EPA ration was also decreased $(p=0.045)$ in the $n-3$ group compared to the $n-6$ (Table 12). 
Table 11. Sow' reproduction traits and piglet's performance.

\begin{tabular}{|c|c|c|c|c|c|c|c|c|c|}
\hline \multirow{2}{*}{ Trait } & \multicolumn{3}{|c|}{ Treatments $^{a}$} & \multirow{2}{*}{ SEM $^{b}$} & \multicolumn{5}{|c|}{$p$-Value ${ }^{c}$} \\
\hline & Control & n-3 & $n-6$ & & Treatment & Time & Diet*Time & $\mathrm{C} 1$ & $\mathrm{C} 2$ \\
\hline \multicolumn{10}{|l|}{ Results of sows } \\
\hline \multicolumn{10}{|l|}{$\begin{array}{c}\text { Number of piglets per } \\
\text { litter, } n\end{array}$} \\
\hline Total born & 12.33 & 13.67 & 13.00 & 1.066 & 0.670 & - & - & 0.447 & 0.666 \\
\hline Born alive & 11.33 & 13.00 & 11.75 & 0.659 & 0.201 & - & - & 0.202 & 0.202 \\
\hline Stillborn & 0.22 & 0.44 & 0.75 & 0.186 & 0.327 & - & - & 0.232 & 0.426 \\
\hline Mummified & 0.22 & 1.00 & 0.50 & 1.691 & 0.144 & - & - & 0.146 & 0.261 \\
\hline Time to first suckle & 10.99 & 14.31 & 18.50 & 1.028 & $<0.001$ & - & - & $<0.001$ & $<0.001$ \\
\hline \multicolumn{10}{|l|}{ Piglets body weight, kg } \\
\hline $1 \mathrm{~d}$ & 1.33 & 1.09 & 1.23 & 0.029 & $<0.001$ & - & - & $<0.001$ & $<0.001$ \\
\hline $21 \mathrm{~d}$ & 4.69 & 4.25 & 4.72 & 0.152 & 0.060 & - & - & 0.261 & 0.035 \\
\hline 1 to $21 \mathrm{~d}$ & 2.79 & 2.91 & 2.95 & 0.040 & 0.013 & $<0.001$ & 0.117 & 0.004 & 0.460 \\
\hline \multicolumn{10}{|c|}{$\begin{array}{l}\text { Piglets average daily gain, } \\
\text { kg/day }\end{array}$} \\
\hline 1 to $7 \mathrm{~d}$ & 0.14 & 0.13 & 0.15 & 0.008 & 0.277 & - & - & - & - \\
\hline 7 to $14 \mathrm{~d}$ & 0.16 & 0.19 & 0.19 & 0.008 & 0.015 & - & - & 0.003 & 0.552 \\
\hline 14 to $21 \mathrm{~d}$ & 0.16 & 0.16 & 0.15 & 0.008 & 0.739 & - & - & - & - \\
\hline 1 to $21 \mathrm{~d}$ & 0.15 & 0.16 & 0.16 & 0.005 & 0.649 & $<0.001$ & 0.023 & 0.661 & 0.554 \\
\hline
\end{tabular}

${ }^{a}$ Sows fed with a Control milk (Control), supplemented with cow's milk enriched with n-3 or n-6. ${ }^{b}$ SEM, standard error of the mean. ${ }^{c} \mathrm{C} 1$, contrast Control vs. n-3+n-6; C2, contrast n-3 vs. $n-6$.

Table 12. Piglet serum fatty acids profile at 1 and 14 days age.

\begin{tabular}{|c|c|c|c|c|c|c|c|c|c|c|c|c|}
\hline \multirow{3}{*}{ Fatty acids $(\mu \mathrm{g} / \mathrm{mL})^{a}$} & \multicolumn{6}{|c|}{ Treatments $^{b}$} & \multirow{3}{*}{ SEM $^{c}$} & \multirow{2}{*}{\multicolumn{5}{|c|}{$p$-Value ${ }^{\mathrm{d}}$}} \\
\hline & \multicolumn{2}{|c|}{ Control } & \multicolumn{2}{|c|}{$n-3$} & \multicolumn{2}{|c|}{$n-6$} & & & & & & \\
\hline & D1 & D14 & D1 & D14 & D1 & D14 & & Treatment & Time & Treat*Time & C1 & $\mathrm{C} 2$ \\
\hline Myristic, C14:0 & 1.54 & 1.12 & 1.85 & 1.14 & 1.81 & 0.96 & 0.215 & 0.724 & 0.004 & 0.675 & 0.543 & 0.603 \\
\hline Palmitic, C16:0 & 23.90 & 22.80 & 25.58 & 24.47 & 24.46 & 22.94 & 1.071 & 0.357 & 0.149 & 0.975 & 0.346 & 0.273 \\
\hline Stearic, C18:0 & 13.98 & 10.88 & 13.54 & 10.83 & 13.41 & 11.44 & 0.632 & 0.915 & $<0.001$ & 0.691 & 0.830 & 0.721 \\
\hline Elaidic, 18:1t & 0.61 & 0.26 & 0.40 & 0.21 & 0.51 & 0.30 & 0.073 & 0.299 & 0.002 & 0.559 & 0.324 & 0.244 \\
\hline Palmitoleic, C16:1c9 & 5.59 & 4.20 & 6.13 & 4.54 & 5.67 & 4.29 & 0.675 & 0.833 & 0.010 & 0.977 & 0.701 & 0.644 \\
\hline Oleic, C18:1c9 & 25.25 & 23.82 & 23.98 & 21.26 & 22.89 & 21.12 & 1.87 & 0.234 & 0.036 & 0.799 & 0.104 & 0.675 \\
\hline Linoleic, C18:2 n-6 & 5.21 & 21.96 & 5.19 & 23.23 & 5.35 & 23.81 & 0.747 & 0.527 & $<0.001$ & 0.642 & 0.297 & 0.666 \\
\hline $\begin{array}{l}\text { Dihomo- } \gamma \text {-linolenic } \\
\text { acid, C20:3 n-6 }\end{array}$ & 0.98 & 0.52 & 0.97 & 0.69 & 0.68 & 0.67 & 0.090 & 0.293 & 0.005 & 0.095 & 0.979 & 0.124 \\
\hline ARA, C20:4 n-6 & 18.18 & 11.19 & 17.68 & 11.25 & 19.35 & 11.62 & 0.753 & 0.419 & $<0.001$ & 0.709 & 0.686 & 0.217 \\
\hline$\gamma$-Linolenic, C18:3 n-6 & 0.41 & 0.65 & 0.44 & 0.49 & 0.49 & 0.41 & 0.074 & 0.632 & 0.183 & 0.111 & 0.361 & 0.855 \\
\hline$\alpha$-Linolenic, C18:3 n-3 & 0.05 & 0.39 & 0.08 & 0.41 & 0.04 & 0.40 & 0.037 & 0.780 & $<0.001$ & 0.885 & 0.721 & 0.549 \\
\hline EPA, C20:5 n-3 & 0.40 & 0.12 & 0.61 & 0.19 & 0.36 & 0.14 & 0.051 & 0.016 & $<0.001$ & 0.184 & 0.133 & 0.010 \\
\hline DHA, C22:6 n-3 & 3.82 & 1.60 & 4.00 & 1.75 & 4.47 & 1.83 & 0.282 & 0.385 & $<0.001$ & 0.693 & 0.287 & 0.383 \\
\hline$\sum$ SFA & 39.48 & 34.90 & 40.87 & 36.34 & 39.78 & 35.36 & 0.925 & 0.384 & $<0.001$ & 0.996 & 0.335 & 0.320 \\
\hline$\Sigma U S F A$ & 60.52 & 65.10 & 59.13 & 63.66 & 60.22 & 64.64 & 0.925 & 0.384 & $<0.001$ & 0.996 & 0.335 & 0.320 \\
\hline USFA/SFA & 65.33 & 53.72 & 69.47 & 57.16 & 66.25 & 54.71 & 2.575 & 0.409 & $<0.001$ & 0.981 & 0.360 & 0.330 \\
\hline$\Sigma$ MUFA & 31.32 & 28.26 & 30.55 & 26.05 & 29.07 & 25.71 & 1.425 & 0.326 & 0.006 & 0.841 & 0.175 & 0.558 \\
\hline$\Sigma$ PUFA & 29.36 & 36.83 & 28.59 & 37.62 & 31.12 & 38.93 & 1.582 & 0.406 & $<0.001$ & 0.865 & 0.500 & 0.248 \\
\hline$\sum n-3$ & 4.26 & 2.11 & 4.68 & 2.33 & 4.89 & 2.37 & 0.260 & 0.319 & $<0.001$ & 0.759 & 0.156 & 0.659 \\
\hline$\sum \mathrm{n}-6$ & 25.10 & 34.71 & 23.91 & 35.29 & 26.22 & 36.55 & 1.446 & 0.429 & $<0.001$ & 0.830 & 0.646 & 0.229 \\
\hline$n-6 / n-3$ & 6.03 & 17.15 & 5.34 & 15.75 & 5.26 & 15.83 & 1.254 & 0.696 & $<0.001$ & 0.951 & 0.412 & 0.997 \\
\hline ARA/EPA & 46.75 & 86.62 & 33.92 & 67.48 & 52.73 & 85.28 & 8.411 & 0.092 & $<0.001$ & 0.909 & 0.364 & 0.045 \\
\hline
\end{tabular}

a ARA: arachidonic acid; EPA: eicosapentaenoic acid; DHA: docosahexaenoic acid; $\Sigma$ SFA $=\Sigma$ saturated fatty acids; $\Sigma$ USFA $=\Sigma$ unsaturated fatty acids; USFA/SFA: unsaturated/saturated fatty acids; $\Sigma$ MUFA $=\Sigma$ monounsaturated fatty acids; $\Sigma$ PUFA $=\Sigma$ polyunsaturated fatty acids; $\Sigma$ n-3 = sum of n-3 fatty acids; $\Sigma$ n- $6=$ n-6: sum of n-6 fatty acids; n- $6 / n-3$, ratio of total n-6 to total n-3 fatty acids; ARA/EPA: ratio of arachidonic acid to eicosapentaenoic acid. ${ }^{\mathrm{b}}$ Sows fed with a Control milk (C), supplemented with cow's milk enriched with n-3 or n-6. ${ }^{c}$ SEM, standard error of the mean. ${ }^{d} \mathrm{C} 1$, contrast Control vs. n-3+n-6; C2, contrast n-3 vs. n-6.

\section{Discussion}

Supplementation with milk enriched with n-3 and n-6 resulted in significant changes in the FA profile of sows and their offspring, as well as piglet performance. Other studies have also shown that the FA composition of the diet of sows affects milk composition and the performance of piglets $[4,27,28]$; however, there are no studies using naturally enriched cow's milk as a long-term source of PUFA as a model for application in humans. 
Females' body weight loss was observed in all treatments over time, which was expected, since in the lactation period there is a high requirement for milk production associated with inadequate feed intake, when the females begin intense catabolism [29]. This is very similar to what happens in women during breastfeeding, because maternal energy metabolism during human lactation is characterised by augmented glucose production and increased mobilisation of fat from maternal deposits [30].

The serum biochemistry at $\mathrm{d} 1$ of lactation presented several changes in the metabolites between control and omega groups. According to protein metabolism, the serum urea increased, and the total protein decreased in sows supplemented with n-3 and n- 6 at d 1 of lactation. It is already reported that n-3 can play an anabolic role and improve muscle mass by reducing the total available protein [31]. Additionally, it is known that n-3 has antiinflammatory properties, which can also be an important reason for its supplementation during female pregnancy and lactation, since immunological issues are one of many challenges that the female encounters after farrowing.

The balance of the immune system, which involves metabolic processes such as the regulation of cytokines, can alter blood levels of total protein when supplemented with different lipid profiles. PUFA supplementation may be able to reduce certain inflammatory proteins [32] and increase other anti-inflammatory agents, just as SFA can contribute to a greater inflammatory state and increase the concentration of pro-inflammatory cytokines in the blood [33]. Even so, interpretation of the differences between treatments is very complicated because the immediate post-farrowing period is followed by changes in glomerular filtration rate, DM intake and muscle mass, which may have variable effects on blood metabolites [34].

Cholesterol metabolism was also influenced by the sows' supplementation, where the females fed with n-3 and n- 6 diets presented higher levels of VLDL compared to those fed a Control diet. This result can be explained by the lipid metabolism in the small intestine, since long-chain FA are transported in the form of TG by VLDL (the main carrier). It is also important to remember that in the final third of pregnancy there are usually reductions in FA synthesis and LPL activity and an increase in triglycerides and insulin resistance. This lipolysis leads to an accumulation of lipolytic products in the main destination, the liver. Therefore, in this context it is normal to find higher values for VLDL and LDL, since maternal hyperlipidaemia results in an increase mainly in TG-rich lipoproteins, which transport LC-PUFA [35].

A 22\% reduction in serum LDL-cholesterol levels in sows supplemented with enriched cow milk may be associated with the lower saturated and higher unsaturated FA content in that diet compared to that of the Control group. Some saturated FA of chain length $10-18$ carbons were reported to elevate levels of mRNA para PGC- $1 \beta$, which activates the family of SREBPs and regulates at least 30 genes involved in the synthesis and metabolism of cholesterol, including genes for LDL [36]. In the same way, others suggest that a great amount of linoleic acid in a diet can decrease blood cholesterol and LDL-cholesterol concentrations, particularly when it replaces the common saturated FA [37]. Consequently, the present results suggest that the milk enriched with PUFA may have a beneficial effect on maternal health.

Complementing the effect of enriched milk on lipid metabolism, serum triglyceride concentrations tended to increase in females supplemented with $n-3$ and $n-6$ relative to the Control group. According to Azain [38], triglycerides in sow serum can be considered as an index of survival for piglets because the triglycerides are metabolised rapidly to ketone bodies, can readily cross the placenta and are used in the developing foetus for the synthesis of lipids and to spare glucose. In this sense, ketogenic agents have the potential to improve foetal energy stores at birth, and consequently, improve the rate of survival [38].

At the end of pregnancy, foetal growth is maximum, the requirements for LC-PUFA are improved and the lipoprotein receptors present in the placenta capture these molecules and diffuse into the foetal plasma [39]. Little glycerol is transported, as the number of ketone bodies present can be important in conditions of maternal hyperketonaemia, and 
the demand for cholesterol by the foetus is high. However, what satisfies their needs is the biosynthesis of foetal cholesterol since maternal cholesterol contributes substantially to this [39].

This indicates that supplementation of sows with enriched cow's milk may contribute to improved piglet development. However, despite those changes in serum biochemistry at $\mathrm{d} 1$ of lactation verified in our study, all those parameters are within the normal range for the lactation period, as previously described by [34]. Results contradictory to the present study were reported by [40] where the administration of cow's milk enriched with PUFA as a supplement to rats resulted in increased serum HDL and a reduction in triglyceride, VLDL and LDL levels.

Additionally, at $\mathrm{d} 1$ of lactation, there were some differences in serum FA profile among the treatments. Sows fed n-3 presented higher levels of palmitic acid and a tendency for lower levels of stearic acid compared to those fed n-6, which may be due to the de novo synthesis of FA. The biosynthesis of FA occurs in the cytosol from the addition of acetyl$\mathrm{CoA}$ in the form of malonyl-CoA, and the main FA produced is palmitic acid [36,41]. In the endoplasmic reticulum and mitochondria, this acid can be elongated to synthesise stearic acid. Both can be precursors of palmitoleic and oleic MUFA, common in animal tissues. It is suggested that the n-3 treatment favoured a greater availability of acetyl-CoA in the cytosol for the higher formation of palmitic acid, and the n- 6 acted on the endoplasmic reticulum, favouring the formation of malonyl-CoA and $\mathrm{NAPDH}$, or on the mitochondria to promote the synthesis of acetyl-CoA and NADPH as substrates for stearic acid [36,41].

The FA supplementation is known to alter the expression of some genes for the desaturase enzymes responsible for synthesising palmitoleic and oleic acids from palmitic and stearic acids, respectively [36,41]. Despite no statistical effect for oleic acid, sows fed with n-3 presented $27 \%$ higher values compared to the $n-6$ group. Additionally, a tendency to decrease linoleic acid (18:2 n-6) in sows supplemented with enriched milk might be attributed to the use of this FA to generate EPA and DHA. Sows fed n-3 and n-6 had 10.34\% higher EPA and 32.50\% higher DHA compared to the Control group. As explained above, PUFA can modulate the expression of the genes for desaturase enzymes that convert linoleic and linolenic acids to EPA, DPAn-3 and DHA [36]. Furthermore, the higher concentration of serum $\gamma$-linolenic acid (18:3 n6) in the n-3 group compared to $n-6$ may also have occurred by modulating the expression of genes for the enzymes presented above.

Fritsche, Huang and Cassity [42] fed sows with fish oil or a Control diet and found that the content of n-3 PUFA in the serum of sows fed with linseed oil increased six-fold over that in serum of sows fed with a Control diet; also, levels of arachidonic acid in maternal serum increased by approximately $50 \%$, and similar changes were reflected on the FA profiles of sows' milk. Similarly, [43] studied sows fed with linseed or linseed oil during the last third of gestation and found increases in PUFA and n-3 FA and a decrease in the $n-6 / n-3$ ratio in the milk and blood of sows and in carcasses of newborn piglets.

Even though there were no changes in the $n-6 / n-3$ ratio in sow's serum among treatments, animals fed n-3 and n-6 diets had a lower n-6/n-3 ratio in colostrum (d 1 of lactation) and sow's milk (d 14 of lactation) compared to the Control group, similar to the results of [43]. These changes in colostrum are mainly due to the linseed oil added to the cows' diets. Even though the ARA concentration was higher in the n- 6 group, this result is due to the better-quality PUFA profile. The individual contents of each family of omega-FA are extremely relevant, but when it comes to the metabolism and roles of FA, the total $n-6 / n-3$ balance may be more relevant than the individual contents, as we can see in this case.

So far, the results of the present study showed that PUFA supplementation to sows may not only improve the health parameters of the sow but also improve the colostrum and milk FA profiles, providing better-quality feeding to the piglets (greater amounts of PUFA), which in turn can improve their survival rate and health. The essential FA are fundamental to several functions in the body, such as maturation and activities of 
the nervous system [44], modulation of the immune system and allergic diseases [45], maturation of the visual system [46] and cognitive and motor development [47]. It is relevant to understand the effects of these FA, since AA and DHA accumulate in the brain during the initial period of postnatal development when milk represents the only source of fat [48].

In the present study, no differences were noted among treatments for the total number of piglets born, born alive or stillborn; however, the n-3 group had 1.34 more piglets than the Control group. Moreover, when we look at the data of the percentage of live piglets born per litter, we can find $91 \%$ for the Control group, 95\% for the n-3 group and $90 \%$ for the n-6 group. Mateo et al. [49] supplemented gilts with milk enriched with n-3 and reported no differences among groups in the total number of piglets born, born alive or stillborn. However, there are studies in humans and animals that report the positive effects of PUFA supplementation on reproductive aspects such as improvements in embryo morphology and pregnancy rates. They attribute this positive impact on fertility as likely to include improved oocyte quality, embryo implantation, reproductive hormones or cycle functioning [50-52].

Additionally, the shorter time to first suckling by piglets in the Control group can be correlated with higher newborn body weight (BW) of this group, since it is generally acknowledged that heavier piglets have more rapid access to the teats [53]. However, it did not play an essential role in this study in the BW at 21 days and the ADG, because from $d$ 0-21, the piglets from sows supplemented with enriched milk increased their BW by $140 \mathrm{~g}$ more than those in the Control group. The higher ADG for $\mathrm{n}-3$ and $\mathrm{n}-6$ groups from d 7-14 compared to the Control group occurred because PUFA are critical to the formation of tissues and regulation of the immune functions, and they are brain lipid components, having significant effects on brain development and function and, thus, behaviour [54]. Even though there were differences in body weight of the newborns, all the results were normal, as expected. These results might also be indicative that the supply of PUFA-enriched milk can improve the energy supply from d 7-14 of life for piglets.

Supplementation with PUFA n-3 has been an effective strategy to reduce the incidence of premature birth, and also to decrease the number of babies born with low weight [55]. In the present study the groups supplemented with milk enriched with n-3 and n-6 presented better weight gain, and this can benefit babies born prematurely, since they are usually born lighter. Harauma et al. [56], in their study with rats, showed that a proper balance between PUFA sources can provide better weight gain.

Rooke et al. [57] also suggested that the increase in growth in piglets from sows fed with a diet enriched with salmon oil was a consequence of improved piglet health status (i.e., brain FA composition). Similar to the present data, [49] reported no differences in initial piglet BW according to treatments, but at $\mathrm{d} 10$ and d 21 of lactation, the BW of piglets from sows fed with n-3 were higher than the Control group. Rooke et al. [57] reported that sows fed with diets enriched with n-3 produced lighter pigs at birth, but these piglets had a higher pre-weaning survival rate than the Control group. Other studies also reported indications that supplementation with n-3 and n-6 FA in the diet of gilts can benefit pregnant and lactating sows under catabolic conditions, improving foetal growth, neonatal health and lactation performance [58,59].

It was recently shown that the FA profile of the plasma and tissues of suckling piglets is highly dependent on the maternal dietary composition, and these results persist for up to 3 weeks after weaning [12]. In the present study, the milk enriched with n-3 supplemented to pregnant and lactating sows resulted in a significant increase in the serum EPA of piglets by $90.91 \%$ compared to the $n-6$ group, from d 0-14. Consequently, the ARA/EPA ratio was lower for milk enriched with n-3, due to the higher amount of $\alpha$-linolenic acid in the maternal n-3 group, which must be converted to a 20-carbon FA, EPA (20:5 n-3) and a 22-carbon FA, DHA (22:6 n-3) through $\Delta 6$-desaturase, $\Delta 5$-desaturase and elongase enzyme metabolic pathways [5,36]. Even though we found a higher concentration of EPA 
in colostrum, the increase of this FA in the blood of piglets was unrelated, since collection was carried out in the piglets before suckling.

EPA is known to be crucial for healthy neural and brain growth and development [5]. In our results we saw a significant increase in EPA in piglets' serum FA, demonstrating that the sows supplemented with milk enriched with n-3 can improve piglet development. These results also suggested that the FA composition of piglets' serum under a maternal diet supplemented with enriched cow's milk might be attributed not only to the incorporation of these fatty acids from the diet, but also to possible activation of their biosynthesis in tissues.

Brazle et al. [60] reported an increase in n-3 LC-PUFA in the placenta of sows fed with $\alpha$-linolenic acid-rich diet during gestation, suggesting the synthesis of n-3 LC-PUFA from dietary $\alpha$-linolenic acid, which can be transferred to the piglets through the placenta. This is similar to that observed in human subjects, where n-3 LC-PUFA are transferred from mother to foetus by a specific placenta transporter called plasma membrane fatty acid-binding protein [61]. Quelen, Boudry and Mourot [28] also found that the maternal diet influenced the FA composition of piglet tissues. Piglets born from sows fed with linseed oil presented higher proportions of n-3 LC-PUFA than those born from sows on a basal diet, whereas in the plasma the proportions of EPA and DHA were higher with the supplemented diet. The same authors also concluded that the maternal dietary $\alpha$-linolenic acid content seems to be necessary for the deposition of n-3 LC-PUFA in foetal tissues.

Farmer and Petit [43] showed that feeding linseed or linseed oil can also bring about increases in DHA in the carcass and brain tissues of 1-d-old piglets. Bazinet, McMillan and Cunnane [62] reported that piglets from sows on a diet supplemented with $\alpha$-linolenic acid had $54 \%$ more DHA in the liver and $24 \%$ more in the brain at $14-\mathrm{d}$ old compared to the piglets from sows on a control diet. Similarly, Groot et al. [63], in a human study, reported that maternal PUFA supplementation during pregnancy increased the proportion of EPA two-fold in the plasma of newborns at birth. These studies confirm that PUFA supplementation can increase LC-PUFA status in the newborn, so it is essential to consider the lipid composition of foods such as milk and its derivatives in the diet of pregnant women, as it directly reflects on the FA profile of their offspring. Since pigs have a metabolism very similar to that of humans, the results of the present study show the great potential for pregnant women, and also for their newborn babies, of consuming cow's milk enriched with PUFA.

\section{Conclusions}

In conclusion, our results indicate that the gilts supplemented with cow's milk naturally enriched with n-3 and n- 6 from 34 days of age until the end of lactation showed an effect on the FA profile of their offspring and themselves, it being important to note that in piglets there was a significant increase in EPA in the n-3 treatment. Regarding the females' metabolism, there was a reduction in LDL for the n-3 and n- 6 treatments, besides improving the performance of piglets with better average body weight in the lactation period from d 1-21.

Supplementary Materials: The following are available online at https:/ /www.mdpi.com/article/ 10.3390/nu13061942/s1, Figure S1: Scheme of the physiological phases of the swine females and consumption of enriched milk in each phase of the experiment, Table S1: Sow's performance from 1st to 21st day of lactation.

Author Contributions: Conceptualization, L.G.R., T.H.d.S., A.F.C.d.A. and A.S.N.; methodology, A.F.C.d.A., S.M.M.K.M., D.P.D.L. and A.S.N.; validation, A.S.N.; formal analysis, T.H.d.S. and F.d.O.B.; investigation, L.G.R.; data curation, L.G.R., G.M.R., C.H.G.M., M.S.V.S. and S.M.M.K.M.; writing—original draft preparation, L.G.R. and S.M.M.K.M.; writing—review and editing, L.G.R., T.H.d.S., M.S.V.S., N.R.B.C., S.M.M.K.M., M.X.d.S.O. and A.S.N.; visualization, A.F.C.d.A., N.R.B.C., S.M.M.K.M. and A.S.N.; supervision, S.M.M.K.M. and A.S.N.; project administration, L.G.R. and A.S.N.; funding acquisition, A.S.N. All authors have read and agreed to the published version of the manuscript. 
Funding: This research was funded by São Paulo Research Foundation (FAPESP), grant number 2015/19393-8 and Coordenação de Aperfeiçoamento de Pessoal de Nível Superior-Brasil (CAPES)Finance Code 001. The APC was funded by São Paulo Research Foundation (FAPESP), grant number 2015/19393-8.

Institutional Review Board Statement: The study was conducted according to the guidelines of the Declaration of Helsinki and approved by the Animal Care and Use Committee of the School of Animal Science and Food Engineering at the University of São Paulo (protocol code 4939070317/2017).

Informed Consent Statement: Not applicable.

Acknowledgments: The authors would like to thank the São Paulo Research Foundation (FAPESP) by the financial support (Grant $n^{\circ}$ 2015/19393-8) and Coordenação de Aperfeiçoamento de Pessoal de Nível Superior-Brasil (CAPES)-Finance Code 001.

Conflicts of Interest: The authors declare no conflict of interest.

$\begin{array}{ll}\text { Abbreviations and Acronyms } \\ \text { ARA } & \text { arachidonic acid (20:4 n-6) } \\ \text { ADG } & \text { average daily gain } \\ \text { AI } & \text { artificial insemination } \\ \text { AA } & \text { arachidonic acid (20:4 n-6) } \\ \text { BW } & \text { body weight } \\ \text { DHA } & \text { docosahexaenoic acid (22:6 n-3) } \\ \text { DPAn-3 } & \text { docosapentaenoic acid (22:5 n-3) } \\ \text { EPA } & \text { eicosapentaenoic acid (20:5 n-3) } \\ \text { FA } & \text { fatty acid(s) } \\ \text { FAME } & \text { fatty acid methyl ester(s) } \\ \text { HDL } & \text { high-density lipoprotein } \\ \text { LC-PUFA } & \text { long-chain polyunsaturated fatty acid(s) } \\ \text { LDL } & \text { low-density lipoprotein } \\ \text { mRNA } & \text { messenger RNA } \\ \text { MUFA } & \text { monounsaturated fatty acid(s) } \\ \text { PUFA } & \text { polyunsaturated fatty acid(s) } \\ \text { TG } & \text { triglicerydes } \\ \text { VLDL } & \text { very-low-density lipoprotein }\end{array}$

\section{References}

1. Serhan, C.N.; Chiang, N.; Van Dyke, T.E. Resolving inflammation: Dual anti-inflammatory and pro-resolution lipid mediators. Nat. Rev. Immunol. 2008, 8, 349-361. [CrossRef]

2. Guadarrama-López, A.L.; Valdés-Ramos, R.; Martínez-Carrillo, B.E. Type 2 diabetes, PUFAs, and vitamin D: Their relation to inflammation. J. Immunol. Res. 2014, 2014. [CrossRef]

3. Campoy, C.; Escolano-Margarit, V.; Anjos, T.; Szajewska, H.; Uauy, R. Omega 3 fatty acids on child growth, visual acuity and neurodevelopment. Br. J. Nutr. 2012, 107. [CrossRef]

4. Koletzko, B.; Larqué, E.; Demmelmair, H. Placental transfer of long-chain polyunsaturated fatty acids (LC-PUFA). J. Perinat. Med. 2007, 35. [CrossRef]

5. Gibson, R.A.; Muhlhausler, B.; Makrides, M. Conversion of linoleic acid and alpha-linolenic acid to long-chain polyunsaturated fatty acids (LCPUFAs), with a focus on pregnancy, lactation and the first 2 years of life. Matern. Child Nutr. 2011, 7, 17-26. [CrossRef] [PubMed]

6. Chen, S.; Bobe, G.; Zimmerman, S.; Hammond, E.G.; Luhman, C.M.; Boylston, T.D.; Freeman, A.E.; Beitz, D.C. Physical and sensory properties of dairy products from cows with various milk fatty acid compositions. J. Agric. Food Chem. 2004, 52, $3422-3428$. [CrossRef] [PubMed]

7. Chilliard, Y.; Ferlay, A. Dietary lipids and forages interactions on cow and goat milk fatty acid composition and sensory properties. Reprod. Nutr. Dev. 2004, 44, 467-492. [CrossRef]

8. Bauer, J.E.; Heinemann, K.M.; Lees, G.E.; Waldron, M.K. Retinal functions of young dogs are improved and maternal plasma phospholipids are altered with diets containing long-chain n-3 polyunsaturated fatty acids during gestation, lactation, and after weaning. J. Nutr. 2006, 136, 1994-1997. [CrossRef] [PubMed]

9. Zhang, R.H.; Mustafa, A.F.; Zhao, X. Blood metabolites and fatty acid composition of milk and cheese from ewes fed oilseeds. Can. J. Anim. Sci. 2006, 86, 547-556. [CrossRef]

10. Duvaux-Ponter, C.; Rigalma, K.; Roussel-Huchette, S.; Schawlb, Y.; Ponter, A.A. Effect of a supplement rich in linolenic acid, added to the diet of gestating and lactating goats, on the sensitivity to stress and learning ability of their offspring. Appl. Anim. Behav. Sci. 2008, 114, 373-394. [CrossRef]

11. Yamamoto, N.; Saitoh, M.; Moriuchi, A.; Nomura, M.; Okyy-ama, H. Effect of dietary alpha-linolenate/linoleate balance on brain lipid compositions and learning ability of rats. J. Lipid Res. 1987, 28, 144-151. [CrossRef] 
12. Lauridsen, C.; Jensen, S.K. Lipid composition of lactational diets influences the fatty acid profile of the progeny before and after suckling. Animal 2007, 1, 952-962. [CrossRef] [PubMed]

13. Missotten, J.; De Smet, S.; Raes, K.; Doran, O. Effect of supplementation of the maternal diet with fish oil or linseed oil on fatty-acid composition and expression of $\Delta 5$ - and $\Delta 6$-desaturase in tissues of female piglets. Animal 2009, 3, 1196-1204. [CrossRef]

14. Kobayashi, E.; Hishikawa, S.; Teratani, T.; Lefor, A.T. The pig as a model for translational research: Overview of porcine animal models at Jichi Medical University. Transplant. Res. 2012, 1, 1-8. [CrossRef] [PubMed]

15. Oliveira, M.X.S.; Palma, A.S.V.; Reis, B.R.; Franco, C.S.R.; Marconi, A.P.S.; Shiozaki, F.A.; Reis, L.G.; Salles, M.S.V.; Netto, A.S. Inclusion of soybean and linseed oils in the diet of lactating dairy cows makes the milk fatty acid profile nutritionally healthier for the human diet. PLOS ONE 2021, 16, e246357. [CrossRef]

16. Rostagno, H.S.; Albino, L.F.T.; Donzele, J.L.; Gomes, P.C.; de Oliveira, R.F.; Lopes, D.C.; Ferreira, A.S.; Barreto, S.L.T.; Euclides, R. Brazilian Tables for Poultry and Swine: Composition of Feedstuffs and Nutritional Requirements; Department of Animal Science, UFV: Viçosa, Brazil, 2017; ISBN 9788560249725.

17. Rodríguez-Ruiz, J.; Belarbi, E.H.; Sánchez, J.L.G.; Alonso, D.L. Rapid simultaneous lipid extraction and transesterification for fatty acid analyses. Biotechnol. Tech. 1998, 12, 689-691. [CrossRef]

18. Hara, A.; Radin, N.S. Lipid extraction of tissues. Anal. Biochem. 1978, 90, 420-426. [CrossRef]

19. Christie, W.W. A simple procedure for rapid transmethylation of glycerolipids and cholesteryl esters. J. Lipid Res. 1982, 23, 1072-1075. [CrossRef]

20. Huang, Z.; Wang, B.; Crenshaw, A.A. A simple method for the analysis of trans fatty acid with GC-MS and AT ${ }^{\mathrm{TM}}-\mathrm{Silar}-90$ capillary column. Food Chem. 2006, 98, 593-598. [CrossRef]

21. Friedewald, W.T.; Robert, I.L.; Fredrickson, D.S. Estimation of the concentration of low-density lipoprotein cholesterolin plasma, without use of the preparative ultracentrifuge. J. Chem. Inf. Model. 2013, 53, 1689-1699.

22. Association of Official Analytical Chemists International-AOAC. Official Methods of Analysis, 18th edition; AOAC International: Gaithersburg, MD, USA, 2005.

23. Goering, H.K.; Van Soest, P.J. Forage Fiber Analyses; U.S. Department of Agriculture: Washington, DC, USA, 1975; pp. $387-598$.

24. Association of Official Analytical Chemists International-AOAC. Official Methods of Analysis, 16th edition; AOAC International: Gaithersburg, MD, USA, 1995.

25. Folch, J.; Lees, M.; Sloane Stanley, G.H. A simple method for the isolation and purification of total lipides from animal tissues. J. Biol. Chem. 1957, 226, 497-509. [CrossRef]

26. Kramer, J.K.G.; Fellner, V.; Dugan, M.E.R.; Sauer, F.D.; Mossoba, M.M.; Yurawecz, M.P. Evaluating acid and base catalysts in the methylation of milk and rumen fatty acids with special emphasis on conjugated dienes and total trans fatty acids. Lipids 1997, 32, 1219-1228. [CrossRef] [PubMed]

27. Eastwood, L.; Leterme, P.; Beaulieu, A.D. Changing the omega-6 to omega-3 fatty acid ratio in sow diets alters serum, colostrum, and milk fatty acid profiles, but has minimal impact on reproductive performance1. J. Anim. Sci. 2014, 92, 5567-5582. [CrossRef] [PubMed]

28. De Quelen, F.; Boudry, G.; Mourot, J. Linseed oil in the maternal diet increases long chain-PUFA status of the foetus and the newborn during the suckling period in pigs. Br. J. Nutr. 2010, 104, 533-543. [CrossRef] [PubMed]

29. Eckhardt, O.H.O.; Horta, F.C.; Parazzi, L.J.; Afonso, E.R.; Martins, S.M.M.K.; Santo, T.A.D.; Barros, F.R.O.; Freitas, J.E.; Rennó, F.P.; Visintin, J.A.; et al. Differences in maternal plane of nutrition and body condition during late gestation coupled with estrus synchronization at weaning do not result in differences in embryonic development at 4 days of gestation. J. Anim. Sci. 2013, 91, 3436-3444. [CrossRef]

30. Mohammad, M.A.; Sunehag, A.L.; Chacko, S.K.; Pontius, A.S.; Maningat, P.D.; Haymond, M.W. Mechanisms to conserve glucose in lactating women during a 42-h fast. Am. J. Physiol. Endocrinol. Metab. 2009, 297, 879-889. [CrossRef] [PubMed]

31. Witard, O.C.; Combet, E.; Gray, S.R. Long-chain n-3 fatty acids as an essential link between musculoskeletal and cardio-metabolic health in older adults. Proc. Nutr. Soc. 2020, 79, 47-55. [CrossRef]

32. Khor, B.H.; Narayanan, S.S.; Chinna, K.; Gafor, A.H.A.; Daud, Z.A.M.; Khosla, P.; Sundram, K.; Karupaiah, T. Blood fatty acid status and clinical outcomes in dialysis patients: A systematic review. Nutrients 2018, 10, 1353. [CrossRef] [PubMed]

33. Rocha, D.M.; Bressan, J.; Hermsdorff, H.H. O papel da ingestão dos ácidos graxos da dieta na expressão de genes inflamatórios: Uma revisão crítica. Sao Paulo Med. J. 2017, 135, 157-168. [CrossRef] [PubMed]

34. Verheyen, A.J.M.; Maes, D.G.D.; Mateusen, B.; Deprez, P.; Janssens, G.P.J.; de Lange, L.; Counotte, G. Serum biochemical reference values for gestating and lactating sows. Vet. J. 2007, 174, 92-98. [CrossRef] [PubMed]

35. Herrera, E.; Ortega-Senovilla, H. Lipid metabolism during pregnancy and its implications for fetal growth. Curr. Pharm. Biotechnol. 2014, 15, 24-31. [CrossRef] [PubMed]

36. Calder, P.C. Functional Roles of Fatty Acids and Their Effects on Human Health. J. Parenter. Enter. Nutr. 2015, 39, 18S-32S. [CrossRef] [PubMed]

37. Mensink, R.P.; Zock, P.L.; Kester, A.D.M.; Katan, M.B. Effects of dietary fatty acids and carbohydrates on the ratio of serum total to HDL cholesterol and on serum lipids and apolipoproteins: A meta-analysis of 60 controlled trials. Am. J. Clin. Nutr. 2003, 77, 1146-1155. [CrossRef] [PubMed]

38. Azain, M.J. Effects of adding medium-chain triglycerides to sow diets during late gestation and early lactation on litter performance. J. Anim. Sci. 1993, 71, 3011-3019. [CrossRef] [PubMed] 
39. Herrera, E.; Amusquivar, E.; López-Soldado, I.; Ortega, H. Maternal lipid metabolism and placental lipid transfer. Horm. Res. 2006, 65, 59-64. [CrossRef] [PubMed]

40. Santos, N.W.; Yoshimura, E.H.; Mareze-Costa, C.E.; Machado, E.; Agustinho, B.C.; Pereira, L.M.; Brito, M.N.; Brito, N.A.; Zeoula, L.M. Supplementation of cow milk naturally enriched in polyunsaturated fatty acids and polyphenols to growing rats. PLoS ONE 2017, 12, e0172909. [CrossRef]

41. Dukes, H.H. Fisiologia dos Animais Domésticos, 12nd ed.; Guanabara Koogan: Rio de Janeiro, Brasil, 2006.

42. Fritsche, K.L.; Huang, S.-C.; Cassity, N.A. Enrichment of omega-3 fatty acids in suckling pigs by maternal dietary fish oil supplementation. J. Anim. Sci. 1993, 71, 1841-1847. [CrossRef]

43. Farmer, C.; Petit, H.V. Effects of dietary supplementation with different forms of flax in late-gestation and lactation on fatty acid profiles in sows and their piglets. J. Anim. Sci. 2009, 87, 2600-2613. [CrossRef]

44. Robert, G.; Jensen Marvin, P.T. Handbook of Milk Composition; Jensen, R.G., Ed.; Academic Press: San Diego, USA, 1995; ISBN 0080533116.

45. Van Elten, T.M.; Van Rossem, L.; Wijga, A.H.; Brunekreef, B.; De Jongste, J.C.; Koppelman, G.H.; Smit, H.A. Breast milk fatty acid composition has a long-term effect on the risk of asthma, eczema, and sensitization. Allergy Eur. J. Allergy Clin. Immunol. 2015, 70, 1468-1476. [CrossRef] [PubMed]

46. Judge, M.P.; Harel, O.; Lammi-Keefe, C.J. A docosahexaenoic acid-functional food during pregnancy benefits infant visual acuity at four but not six months of age. Lipids 2007, 42, 117-122. [CrossRef] [PubMed]

47. Jacobson, J.L.; Jacobson, S.W.; Muckle, G.; Kaplan-Estrin, M.; Ayotte, P.; Dewailly, É. Beneficial effects of a polyunsaturated fatty acid on infant development. J. Pediatr. 2008, 152, 356-364. [CrossRef] [PubMed]

48. Farquharson, J.; Jamieson, E.C.; Logan, R.W.; Cockburn, F.; Ainslie Patrick, W. Infant cerebral cortex phospholipid fatty-acid composition and diet. Lancet 1992, 340, 810-813. [CrossRef]

49. Mateo, R.D.; Carroll, J.A.; Hyun, Y.; Smith, S.; Kim, S.W. Effect of dietary supplementation of n-3 fatty acids and elevated concentrations of dietary protein on the performance of sows. J. Anim. Sci. 2009, 87, 948-959. [CrossRef]

50. Hammiche, F.; Vujkovic, M.; Wijburg, W.; De Vries, J.H.M.; MacKlon, N.S.; Laven, J.S.E.; Steegers-Theunissen, R.P.M. Increased preconception omega-3 polyunsaturated fatty acid intake improves embryo morphology. Fertil. Steril. 2011, 95, 1820-1823. [CrossRef] [PubMed]

51. Moran, L.J.; Tsagareli, V.; Noakes, M.; Norman, R. Altered preconception fatty acid intake is associated with improved pregnancy rates in overweight and obesewomen undertaking in vitro fertilisation. Nutrients 2016, 8, 10. [CrossRef]

52. Nehra, D.; Le, H.D.; Fallon, E.M.; Carlson, S.J.; Woods, D.; White, Y.A.; Pan, A.H.; Guo, L.; Rodig, S.J.; Tilly, J.L.; et al. Prolonging the female reproductive lifespan and improving egg quality with dietary omega-3 fatty acids. Aging Cell 2012, 11, 1046-1054. [CrossRef]

53. Hăbeanu, M.; Gheorghe, A.; Surdu, I.; Chedea, V.S.; Lefter, N.A.; Stoian, G.; Panait, A.-A.-M.-D.; Beia, I. N-3 PUFA enriched hemp seed diet modifies beneficially sow milk composition and piglets' performances. Sci. Pap. Ser. Manag. Econ. Eng. Agric. Rural Dev. 2018, 18, 181-190.

54. Crawford, M. Placental delivery of arachidonic and docosahexaenoic acids: Implications for the lipid nutrition of preterm infants. Am. J. Clin. Nutr. 2000, 71, 275S-284S. [CrossRef] [PubMed]

55. Middleton, P.; Gomersall, J.C.; Gould, J.F.; Shepherd, E.; Olsen, S.F.; Makrides, M. Omega-3 fatty acid addition during pregnancy. Obstet. Gynecol. Surv. 2019, 74, 189-191. [CrossRef]

56. Harauma, A.; Hatanaka, E.; Yasuda, H.; Nakamura, M.T.; Salem, N.; Moriguchi, T. Effects of arachidonic acid, eicosapentaenoic acid and docosahexaenoic acid on brain development using artificial rearing of delta-6-desaturase knockout mice. Prostaglandins Leukot. Essent. Fat. Acids 2017, 127, 32-39. [CrossRef] [PubMed]

57. Rooke, J.A.; Sinclair, A.G.; Edwards, S.A.; Cordoba, R.; Pkiyach, S.; Penny, P.C.; Penny, P.; Finch, A.M.; Horgan, G.W. The effect of feeding salmon oil to sows throughout pregnancy on pre-weaning mortality of piglets. Anim. Sci. 2001, 73, 489-500. [CrossRef]

58. Kim, S.W.; Mateo, R.D.; Yin, Y.L.; Wu, G. Functional amino acids and fatty acids for enhancing production performance of sows and piglets. Asian Australas. J. Anim. Sci. 2007, 20, 295-306. [CrossRef]

59. Williams, A.M.; Safranski, T.J.; Spiers, D.E.; Eichen, P.A.; Coate, E.A.; Lucy, M.C. Effects of a controlled heat stress during late gestation, lactation, and after weaning on thermoregulation, metabolism, and reproduction of primiparous sows. J. Anim. Sci. 2013, 91, 2700-2714. [CrossRef]

60. Brazle, A.E.; Johnson, B.J.; Webel, S.K.; Rathbun, T.J.; Davis, D.L. Omega-3 fatty acids in the gravid pig uterus as affected by maternal supplementation with omega-3 fatty acids. J. Anim. Sci. 2009, 87, 994-1002. [CrossRef] [PubMed]

61. Haggarty, P. Effect of placental function on fatty acid requirements during pregnancy. Eur. J. Clin. Nutr. 2004, 58, 1559-1570. [CrossRef] [PubMed]

62. Bazinet, R.P.; McMillan, E.G.; Cunnane, S.C. Dietary $\alpha$-linolenic acid increases the $n-3$ PUFA content of sow's milk and the tissues of the suckling piglet. Lipids 2003, 38, 1045-1049. [CrossRef] [PubMed]

63. De Groot, R.H.M.; Hornstra, G.; Van Houwelingen, A.C.; Roumen, F. Effect of $\alpha$-linolenic acid supplementation during pregnancy on maternal and neonatal polyunsaturated fatty acid status and pregnancy outcome. Am. J. Clin. Nutr. 2004, 79, 251-260. [CrossRef] [PubMed] 